Prepared in cooperation with the Michigan Department of Environmental Quality

\title{
Comparison of Streamflow and Water-Quality Data Collection Techniques for the Saginaw River, Michigan
}

Scientific Investigations Report 2012-5150 
Cover: The Saginaw River at Bay City, Michigan. (Cover photograph courtesy of Aaron Toth) 


\section{Comparison of Streamflow and Water- Quality Data Collection Techniques for the Saginaw River, Michigan}

By C.J. Hoard, D.J. Holtschlag, J.W. Duris, D.A. James, and D.J. Obenauer

Prepared in cooperation with the Michigan Department of Environmental Quality

Scientific Investigations Report 2012-5150 


\title{
U.S. Department of the Interior \\ KEN SALAZAR, Secretary \\ U.S. Geological Survey \\ Marcia K. McNutt, Director
}

\author{
U.S. Geological Survey, Reston, Virginia: 2012
}

For more information on the USGS - the Federal source for science about the Earth, its natural and living resources, natural hazards, and the environment, visit http://www.usgs.gov or call 1-888-ASK-USGS.

For an overview of USGS information products, including maps, imagery, and publications, visit http://www.usgs.gov/pubprod

To order this and other USGS information products, visit http://store.usgs.gov

Any use of trade, firm, or product names is for descriptive purposes only and does not imply endorsement by the U.S. Government.

Although this information product, for the most part, is in the public domain, it also may contain copyrighted materials as noted in the text. Permission to reproduce copyrighted items must be secured from the copyright owner.

Suggested citation:

Hoard, C.J., Holtschlag, D.J., Duris, J.W., James, D.A., and Obenauer, D.J., 2012, Comparison of streamflow and water-quality data collection techniques for the Saginaw River, Michigan: U.S. Geological Survey Scientific Investigation Report 2012-5150, 28 p. 


\section{Contents}

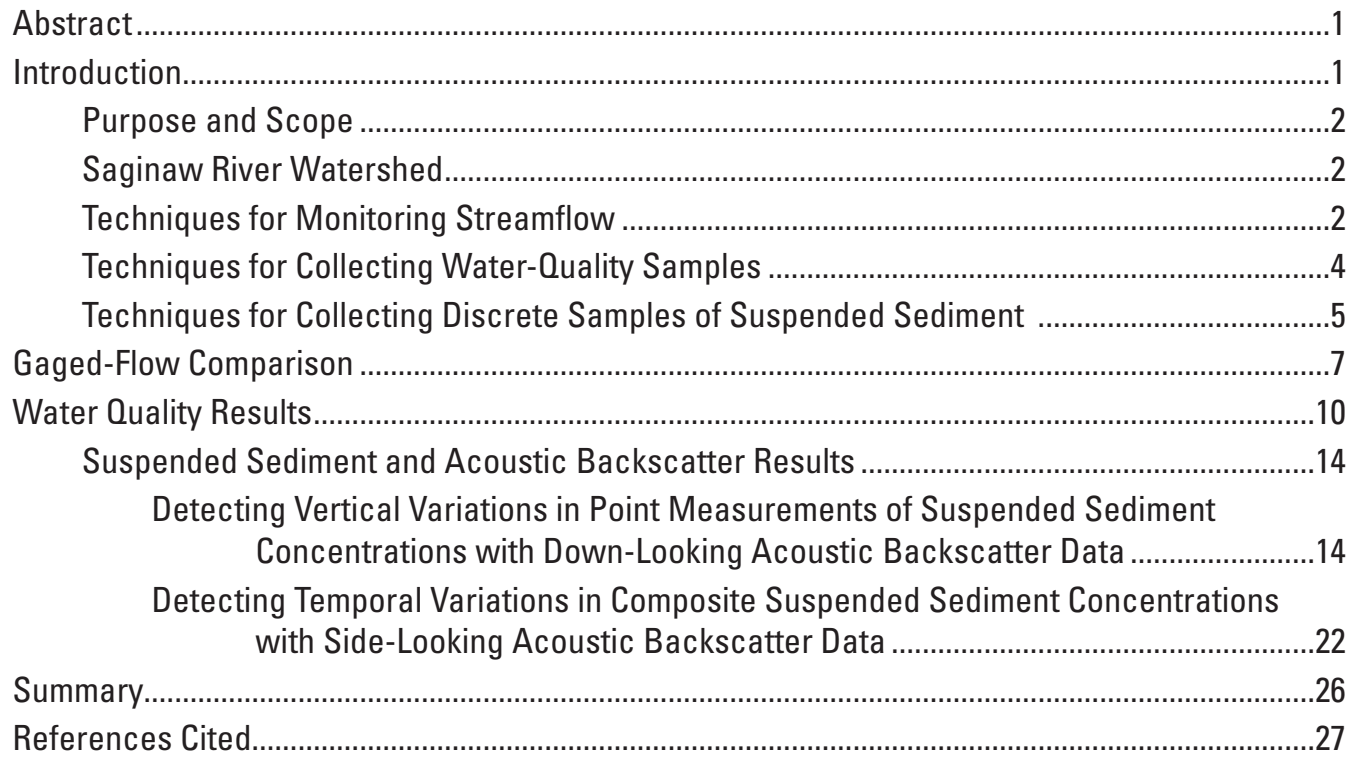

\section{Figures}

1. Map showing location of the Saginaw River study area and the surrounding area in Michigan.

2. Plot showing channel cross-section and grab- and depth integrating multiple vertical sampling locations in the channel of the Saginaw River, Michigan.

3. Map showing discrete suspended-sediment sampling locations near station 04157061, Saginaw River at Bay City, Michigan

4. Graphs showing daily mean and unit flows at $A$, station 04157000 , Saginaw River at Saginaw, and $B$, station 04157061, Saginaw River at Bay City, Michigan from April to September 2009.

5. Graphs showing $A$, residual for daily mean flows between stations 04157000 , Saginaw River at Saginaw, and 04157061, Saginaw River at Bay City, Michigan, and $B$, the relative percent difference of daily mean flows for the two stations.

6. Graphs showing water levels and flows at station 04157061, Saginaw River at Bay City, Michigan during suspended-sediment sampling on $A$, July 30,2009 , and $B$, August 12, 2009.

7. Backscatter contour plot showing locations of suspended-sediment concentration measurements along two vertical profiles sampled on July 30, 2009, from 11:01 to 11:05 a.m. at station 04157061, Saginaw River at Bay City, Michigan .

8. Backscatter contour plot showing locations of suspended-sediment concentration measurements along two vertical profiles sampled on August 12, 2009 from 11:03 to 11:07 a.m. at station 04157061, Saginaw River at Bay City, Michigan ...... 
9 Graph showing relation between acoustic backscatter and suspendedsediment concentrations from samples along two vertical profiles in July and August 2009 at station 04157061, Saginaw River at Bay City, Michigan

10. Graph showing frequency of flow reversals in the Saginaw River at Bay City, Michigan in May and August 2009 23

11. Graph showing cumulative frequency distribution of integrated flow velocities in the Saginaw River at Bay City, Michigan from April to September 2009...

12. Graph showing relation between signal amplitude and signal-to-noise ratio from Argonaut 500 SL with distance to width bin at the Saginaw River at Bay City, Michigan, from April to September 2009...

13. Graph showing composite suspended-sediment concentration measurements and contemporaneous measurements of acoustic amplitude and signal-tonoise ratios from a side-looking acoustic Doppler current profiler in the Saginaw River at Bay City, Michigan in 2009.

\section{Tables}

1. Physical parameters measured at stations 04156999, Saginaw River at Saginaw, and 04157061, Saginaw River at Bay City, Michigan

2. Summary of nutrient and sediment concentrations measured at station 04156999, Saginaw River at Saginaw, Michigan

3. Summary of nutrient and sediment concentrations measured at station 04157061, Saginaw River at Bay City, Michigan

4. Results of use of the Wilcoxon two-sided signed-ranks test to compare paired depth integrated multiple vertical and surface-grab samples for selected constituents collected at collected at station 04156999, Saginaw River at Saginaw, and 04157061,Saginaw River at Bay City, Michigan and for both stations combined

5. Median relative percent difference for selected constituents in depth integrated multiple vertical and surface-grab samples collected at stations 04156999, Saginaw River at Saginaw, and 04157061, Saginaw River at Bay City, Michigan and for both stations combined

6. Suspended-sediment concentrations and acoustic-backscatter and velocity data from measurements at vertical profiles at station 0415761, Saginaw River at Bay City, Michigan

7. Analysis of variance and parameter estimates for simple linear regression relating suspended-sediment concentrations with acoustic backscatter for two profiles sampled in July and August 2009 at station 04157061, Saginaw River at Bay City, Michigan

8. One-way analysis of covariance and parameter estimates relating suspended-sediment concentrations with depth by profile and sample month at station 04157061, Saginaw River at Bay City, Michigan.

9. Analysis of covariance and parameter estimates for linear regression relating suspended-sediment concentrations with acoustic backscatter for two profiles sampled in July and August 2009 at station 04157061, Saginaw River at Bay City, Michigan 


\section{Conversion Factors, Abbreviations, and Datum Information}

Inch/Pound to SI

\begin{tabular}{lll}
\hline \multicolumn{1}{c}{ Multiply } & By & \multicolumn{1}{c}{ To obtain } \\
\hline inch (in.) & Length & \\
foot (ft) & 2.54 & centimeter $(\mathrm{cm})$ \\
mile (mi) & 0.3048 & meter $(\mathrm{m})$ \\
\hline & 1.609 & kilometer $(\mathrm{km})$ \\
\hline square mile $\left(\mathrm{mi}^{2}\right)$ & Area & \\
\hline & 2.590 & square kilometer $\left(\mathrm{km}^{2}\right)$ \\
\hline gallon (gal) & Volume & liter $(\mathrm{L})$ \\
\hline & 3.785 & \\
\hline foot per second $(\mathrm{ft} / \mathrm{s})$ & Flow rate & meter per second $(\mathrm{m} / \mathrm{s})$ \\
cubic foot per second $\left(\mathrm{ft}^{3} / \mathrm{s}\right)$ & 0.3048 & cubic meter per second $\left(\mathrm{m}^{3} / \mathrm{s}\right)$ \\
\hline
\end{tabular}

Temperature in degrees Celsius $\left({ }^{\circ} \mathrm{C}\right)$ may be converted to degrees Fahrenheit $\left({ }^{\circ} \mathrm{F}\right)$ as follows: ${ }^{\circ} \mathrm{F}=\left(1.8 \times^{\circ} \mathrm{C}\right)+32$

Temperature in degrees Fahrenheit $\left({ }^{\circ} \mathrm{F}\right)$ may be converted to degrees Celsius $\left({ }^{\circ} \mathrm{C}\right)$ as follows: ${ }^{\circ} \mathrm{C}=\left({ }^{\circ} \mathrm{F}-32\right) / 1.8$

Vertical coordinate information is referenced to National Geodetic Vertical Datum of 1929 (NGVD 29).

Horizontal coordinate information is referenced to North American Datum of 1983 (NAD 83).

Altitude, as used in this report, refers to distance above the vertical datum.

Specific conductance is given in microsiemens per centimeter at 25 degrees Celsius $\left(\mu \mathrm{S} / \mathrm{cm}\right.$ at $\left.25^{\circ} \mathrm{C}\right)$.

Concentrations of chemical constituents in water are given in milligrams per liter (mg/L).

$\mathrm{dB} \quad$ Decibel

DIMV Depth Integrating Multiple Vertical

EWI Equal Width Interval

$\mathrm{kHz} \quad$ Kilohertz

NTRU Nephelometric Turbidity Ratio Unit 


\section{Acknowledgement}

The authors wish to thank the Andrew LeBaron and Dawn Roush of Michigan Department of Environmental Quality for providing water use information along the Saginaw River. In addition, the authors thank Peter Cinotto and Bonnie Gray of the USGS for technical reviews of this manuscript. Elizabeth Ciganovich provided the editorial review and formatted this manuscript for publication. 


\title{
Comparison of Streamflow and Water-Quality Data Collection Techniques for the Saginaw River, Michigan
}

\author{
By C.J. Hoard, D.J. Holtschlag, J.W. Duris, D.A. James, and D.J. Obenauer
}

\section{Abstract}

In 2009, the Michigan Department of Environmental Quality and the U.S. Geological Survey developed a plan to compare the effect of various streamgaging and water-quality collection techniques on streamflow and stream water-quality data for the Saginaw River, Michigan. The Saginaw River is the primary contributor of surface runoff to Saginaw Bay, Lake Huron, draining approximately 70 percent of the Saginaw Bay watershed. The U.S. Environmental Protection Agency has listed the Saginaw Bay system as an "Area of Concern" due to many factors, including excessive sediment and nutrient concentrations in the water. Current efforts to estimate loading of sediment and nutrients to Saginaw Bay utilize water-quality samples collected using a surface-grab technique and flow data that are uncertain during specific conditions. Comparisons of current flow and water-quality sampling techniques to alternative techniques were assessed between April 2009 and September 2009 at two locations in the Saginaw River. Streamflow estimated using acoustic Doppler current profiling technology was compared to a traditional stage-discharge technique. Complex conditions resulting from the influence of Saginaw Bay on the Saginaw River were able to be captured using the acoustic technology, while the traditional stage-discharge technique failed to quantify these effects. Water-quality samples were collected at two locations and on eight different dates, utilizing both surface-grab and depth-integrating multiple-vertical techniques. Sixteen paired samples were collected and analyzed for suspended sediment, turbidity, total phosphorus, total nitrogen, orthophosphate, nitrite, nitrate, and ammonia. Results indicate that concentrations of constituents associated with suspended material, such as suspended sediment, turbidity, and total phosphorus, are underestimated when samples are collected using the surfacegrab technique. The median magnitude of the relative percent difference in concentration based on sampling technique was 37 percent for suspended sediment, 26 percent for turbidity, and 9.7 percent for total phosphorus samples collected at both.

Acoustic techniques were also used to assist in the determination of the effectiveness of using acoustic-backscatter information for estimating the suspended-sediment concentration of the river water. Backscatter data was collected by use of an acoustic Doppler current profiler, and a Van Dorn manual sampler was simultaneously used to collect discrete water samples at 10 depths $(3.5,7.5,11,14,15.5,17.5,19.5$, $20.5,22$, and $24.5 \mathrm{ft}$ below the water surface) along two vertical profiles near the center of the Saginaw River near Bay City. The Van Dorn samples were analyzed for suspendedsediment concentrations, and these data were then used to develop a relationship between acoustic-backscatter data. Acoustic-backscatter data was strongly correlated to sediment concentrations and, by using a linear regression, was able to explain 89 percent of the variability. Although this regression technique showed promise for using acoustic backscatter to estimate suspended-sediment concentration, attempts to compare suspended-sediment concentrations to the acoustic signal-to-noise ratio estimates, recorded at the fixed acoustic streamflow-gaging station near Bay City (04157061), resulted in a poor correlation.

\section{Introduction}

The Saginaw Bay watershed is Michigan's largest watershed and drains approximately 15 percent of Michigan's total land area. The Saginaw River accounts for approximately 70 percent of the total drainage to Saginaw Bay, Lake Huron, and is, thus, a major contributor to the overall water quality of Saginaw Bay (Michigan Department of Environmental Quality, 2006). The U.S. Environmental Protection Agency (EPA) lists the Saginaw Bay system as an "Area of Concern" (AOC) owing to impairment of fisheries and loss of recreational value resulting from high amounts of sediment and nutrients (phosphorus and nitrogen) that enter the system (Environmental Protection Agency, 2009).

As indicated in the current Lake Huron Binational Partnership 2008-2010 Action Plan (Environmental Protection Agency, 2009) one of the major efforts that will be conducted by the National Oceanographic and Atmospheric Administration (NOAA), the Michigan Department of Environmental Quality (MDEQ), and the Michigan Department of Natural Resources (MDNR) will be "Managing the Impact of Multiple Stressors in Saginaw Bay." This effort is focused on understanding the combined effects of nutrients, sediments, and 
other stressors in the Saginaw Bay watershed, with the goal of identifying management actions that will improve the health of the Bay (Environmental Protection Agency, 2009). Because this effort is intended to focus on the specific effects that the Saginaw River could be having on Saginaw Bay, having the most accurate data will be important for understanding basic river discharge and constituent loading to Saginaw Bay.

Currently, most sampling efforts conducted by the MDEQ and NOAA rely on a single or three-point grab sample from 1 to $3.3 \mathrm{ft}$ below the surface. This sample is intended to represent the roughly 490 -ft-wide river that ranges in depth from less than $3.3 \mathrm{ft}$ at the banks to approximately $30 \mathrm{ft}$ in the central shipping channel. In 2009, streamflow was measured by the U.S. Geological Survey (USGS) on the Saginaw River using gage height- or stage- to-river discharge relations. Although river-stage measurements themselves are typically accurate, at certain times conditions can affect the accuracy of the computed discharge from the rating curve, which relates stage to discharge. The conditions that may cause the actual flow to deviate from the expected stage-discharge relation can include, but are not limited to, ice formations, certain atmospheric pressure conditions, and wind conditions. Computation of loads of particular constituents based on nonrepresentative samples or stream discharge values could cause a potential bias in our understanding of the nutrient and sediment inputs from the Saginaw River to Saginaw Bay.

During the spring and summer of 2009, the USGS developed a sampling program to evaluate various water-quality and streamflow data-collection techniques on the Saginaw River. The objectives of this program were to 1) compare samples collected by a discrete surface-grab technique to samples collected through the depth-integrating multiplevertical technique (DIMV), 2) compare discharge estimates for the Saginaw River collected using a fixed "side-looking" acoustic Doppler current profiler (ADCP) gage to estimates derived from a standard gage using a stage-discharge relation, 3) compare constituent load estimates for nutrients and sediment to Saginaw Bay utilizing the various flow and waterquality data available, and 4) explore the relation between acoustic backscatter collected from ADCP measurements to sediment concentration.

\section{Purpose and Scope}

The purpose of this report is to describe 1) the evaluation of different collection techniques for water-quality and streamflow data on the Saginaw River and 2) the relation between acoustic backscatter and suspended-sediment concentration for the Saginaw River. Water-quality samples were collected eight times at two sites on the Saginaw River between April 21 and September 8, 2009. During each sampling event at each site, a discrete sample was collected by the surface-grab technique in conjunction with a sample collected by the DIMV technique. Each sample was analyzed for eight constituents in addition to physical parameters measured at the site. Nonparametric statistics were used to evaluate differences in constituent concentration based on the water-quality sampling technique used. Streamflow was monitored at each sampling site; a traditional gage-height recorder was used upstream and a side-looking ADCP gage was used downstream of the site. Forty discrete suspended-sediment samples were collected at various depths in conjunction with vertical ADCP measurements. Acoustic backscatter recorded by the ADCP was related to suspendedsediment concentration.

\section{Saginaw River Watershed}

The Saginaw River watershed is located in the eastcentral portion of Michigan (fig. 1). The Saginaw River is a 22.2-mi-long river (U.S. Geological Survey, 2010) that begins at the confluence of the Shiawassee and Tittabawassee Rivers and ultimately discharges to Saginaw Bay (fig. 1). The river generally flows from the southwest to northeast. Four major tributaries contribute flow to the Saginaw River; the Cass, Flint, Shiawassee, and Tittabawassee Rivers. These rivers combine to drain an area of roughly $6,300 \mathrm{mi}^{2}$, or approximately 70 percent of the entire Saginaw Bay watershed (fig. 1). Land-use characteristics compiled in the 2001 National Land Cover Dataset (Multi-Resolution Land Characteristics Consortium, 2008) indicate that 45 percent of land use in the Saginaw River watershed is agricultural. The remaining area is classified as undeveloped forest and grassland (27 percent), wetland (14 percent), developed (13 percent), and open water (1 percent). The mean annual discharge for the Saginaw River at station 04157000 (fig. 1) for the period from 1992 to 2009 (period of continuous record) is $4,375 \mathrm{ft}^{3} / \mathrm{s}$ (U.S. Geological Survey, 2010). The 30-year average (19712000) minimum and maximum annual temperatures for the watershed are $36.3^{\circ} \mathrm{F}$ and $56.8^{\circ} \mathrm{F}$ respectively (PRISM Climate Group, 2008). The 30-year average annual precipitation for the watershed is 31.4 in. (PRISM Climate Group, 2008).

\section{Techniques for Monitoring Streamflow}

Discharge in the Saginaw River was monitored using a combination of discrete flow measurements and data from two USGS streamflow-gaging stations. Discrete discharge measurements were collected near two streamflow-gaging stations using an ADCP. These discrete flow measurements were also collected in conjunction with water-quality sampling events.

Flow in the Saginaw River was continuously monitored at two USGS streamflow-gaging stations. The gage at Saginaw, station 04157000 (fig. 1), measured the altitude of the water surface in the river; this is also known as the stage of the river. To estimate discharge in the river, a stage-discharge relation was developed. This stage-discharge relation was developed by directly measuring the flow of the river over a wide range of river stages. A model is then developed to relate river stage to discharge such that for a given river stage, the discharge in the river can be estimated. 


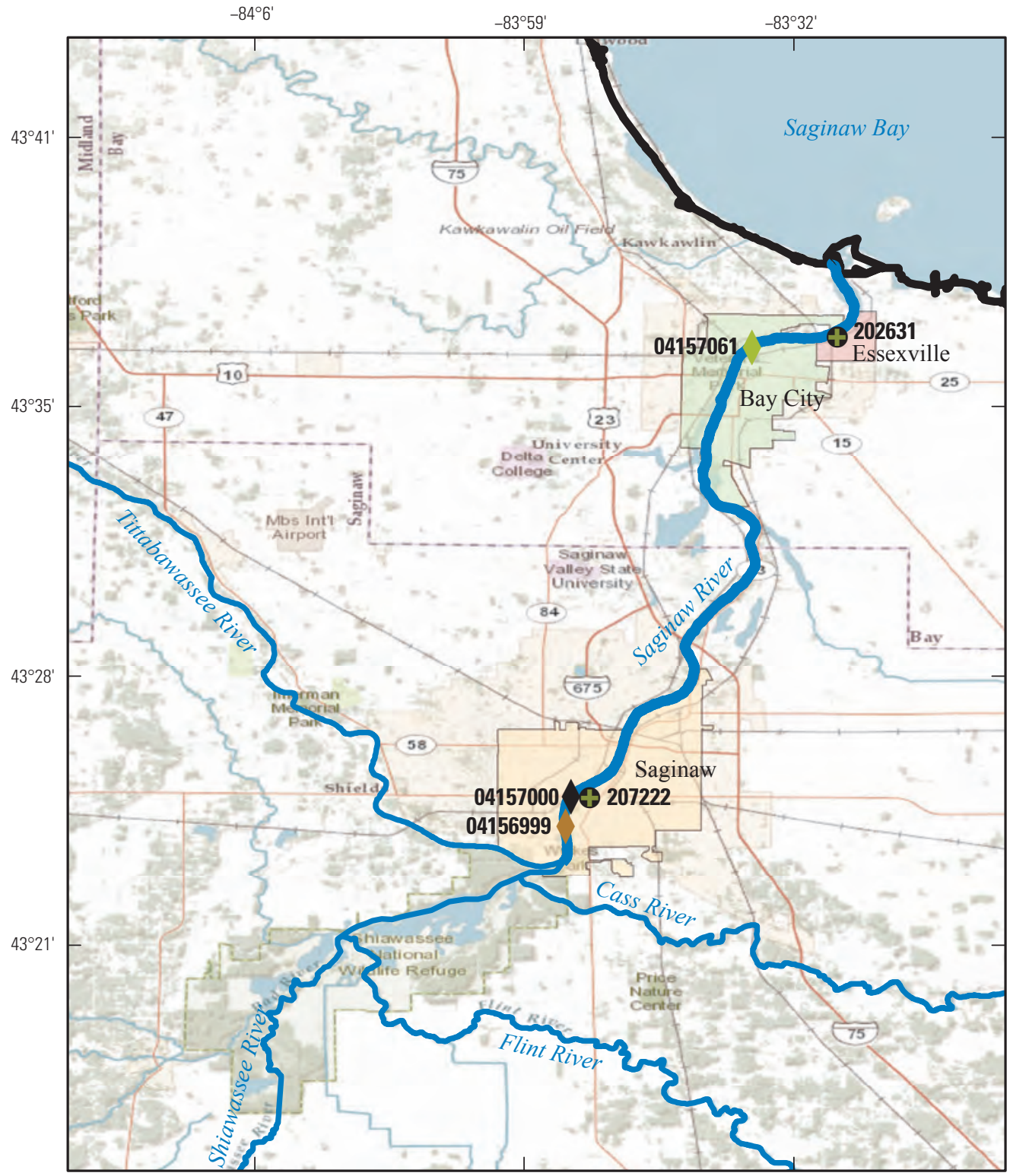

\section{EXPLANATION}

Saginaw River watershed

Saginaw Bay watershed

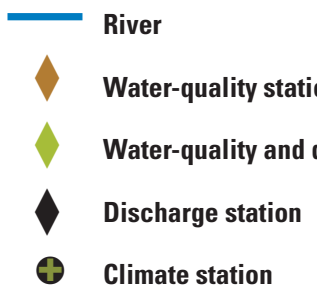

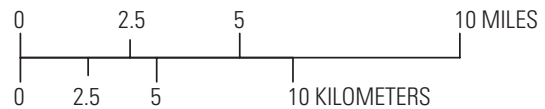

10 KILOMETERS

10 MILES

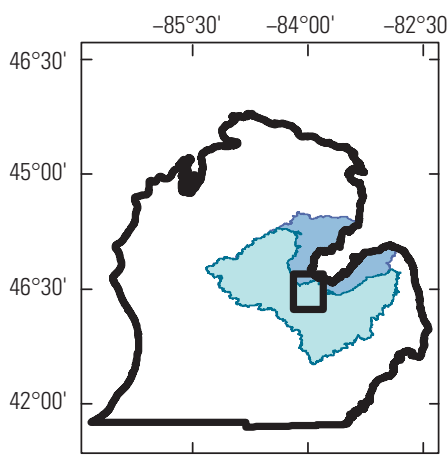

Figure 1. Location of the Saginaw River study area and the surrounding area in Michigan. 
In addition to streamflow-gaging station 04157000 , a new gage 04157061 (fig. 1) was installed further downstream at Bay City between the Liberty and Independence Bridges. Station 04157061 utilized acoustic Doppler technology to measure the velocity of the water for a section of the river. Estimating flow at this gage required the development of an index-velocity rating (Morlock and others, 2001). Once the process for developing the index-velocity rating was complete, the discharge in the river could be estimated.

\section{Techniques for Collecting Water-Quality Samples}

Prior to collecting samples for water-quality assessment, field measurements of physical parameters of the river were collected using a multiparameter water-quality sonde. Standard USGS calibration and measurement procedures (Gibs and others, 2007) for multiparameter instruments were used to collect $\mathrm{pH}$, water temperature, specific conductance, and dissolved oxygen. These physical parameters were measured at the midpoints of the left, center, and right thirds of the river, and the median values of those measurements were recorded. Following the measurement of the physical parameters of the river, samples for water quality were collected.

Water-quality samples were collected from two locations on the Saginaw River for comparison of surface-grab and DIMV techniques. The first water-quality station, number 04156999, was approximately $1 \mathrm{mi}$ upstream from USGS streamflow-gaging station 0415700 (fig. 1). The second water-quality station was at USGS streamflow-gaging station 04157061 . At each water-quality station (04156999 and 04157061), eight sets of paired-grab and integrated samples were collected between April 21 and September 9, 2009. Six samples were collected as part of a routine schedule targeted at the middle of the month, and two samples were event driven and were aimed at collecting samples during high-flow events. During the period of sampling, however, there was a lack of high flow-events, so the event-driven samples were collected during low-flow events in the river that reflect potential backwater conditions from seiche activity on Saginaw Bay.

The surface-grab technique requires the deployment of a 1-L high-density polyethylene (HDPE) sample bottle into the river at approximately $1-3.3 \mathrm{ft}$ depth. The sample bottle was deployed at three points across the width of the channel at the approximate midpoints of the left, center, and right thirds of the channel (fig. 2). These three points correspond roughly with where the physical parameter readings were collected. The water from these three points was then composited into a 3-L HDPE bottle. The water in the 3-L bottle was mixed by shaking the bottle and then was decanted into individual sample bottles. Sample bottles were then processed, stored, and shipped according to USGS protocols (Wilde, 2006).

In addition to the grab sample, a DIMV sample was also collected. Initially, sample collection using the equal-widthinterval (EWI) technique (Wilde, 2006) was attempted, but the river conditions did not meet the criteria for isokinetic collection of a sample. As a result, DIMV samples were collected according to standard USGS protocols (Wilde, 2006). Ten vertical transects were selected at equal widths across the

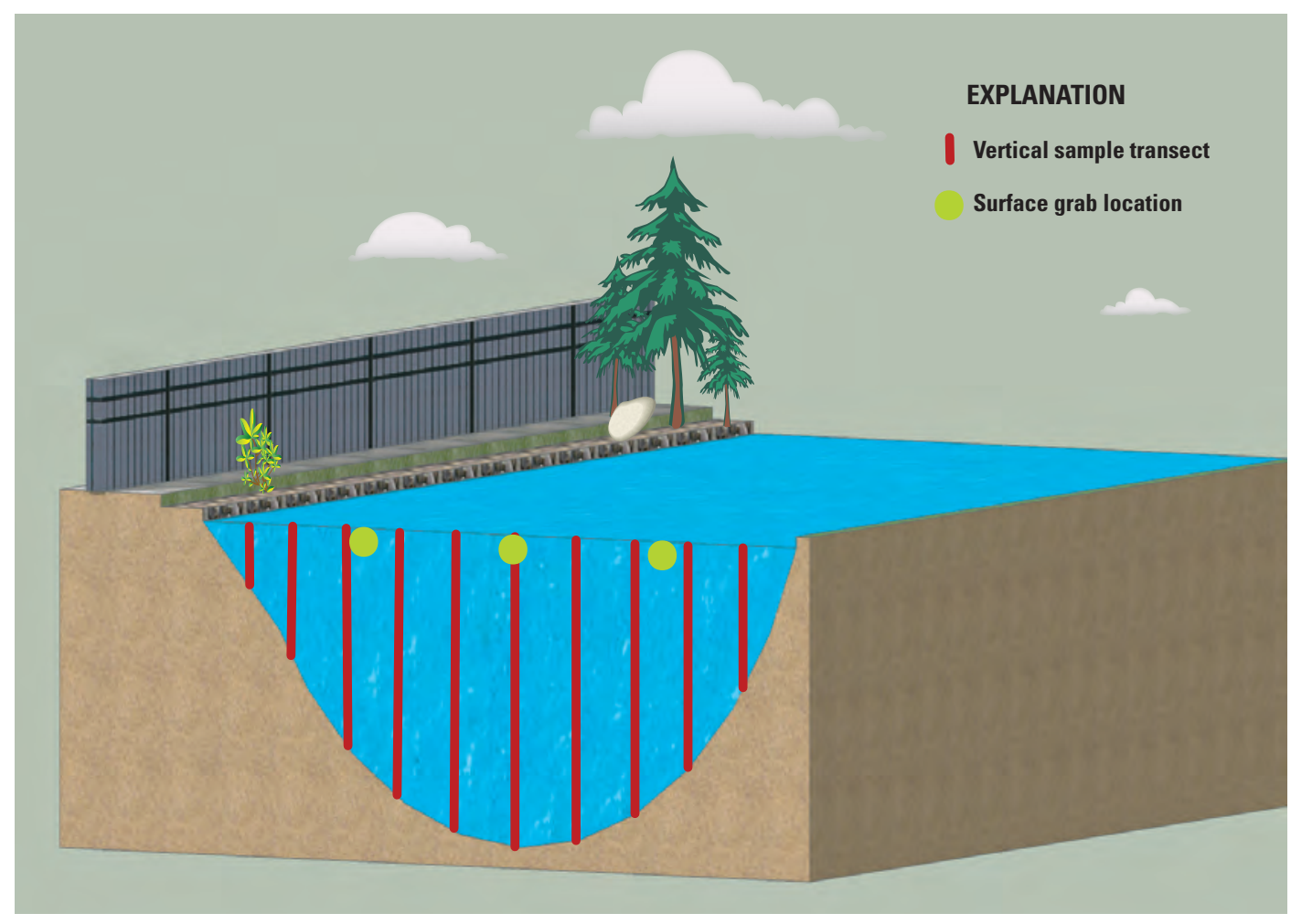

Figure 2. Channel crosssection and grab- and depth integrating multiple vertical sampling locations in the channel of the Saginaw River, Michigan. 
channel (fig. 2). For the first sampling event on April 21, 2009, a USGS DH-2 sampler (Davis, 2005) equipped with a 5/16-in. inner diameter nozzle was lowered at each transect at a rate of $0.5 \mathrm{ft} / \mathrm{s}$. It was determined that the DH-2 sampler was not necessary because of the low velocity $(<2.0 \mathrm{ft} / \mathrm{sec})$ of the river so, for subsequent events, a USGS DH-95 sampler (Davis, 2005) was used. A DH-95 sampler equipped with a 5/16-in. inner diameter nozzle was deployed from a boat-mounted crane, lowered at a constant rate to the bottom of the channel, and then raised to the surface at the same rate. Water collected in the sampler was composited in a 14-L HDPE churn. After all 10 sections had been sampled and composited in the churn, the churn was mixed using the churn paddle and continuously churned while water was decanted into individual sample bottles. As with the grab sample, the samples were then processed, stored, and shipped according to USGS protocols (Wilde, 2006).

Samples collected from both the surface-grab and DIMV techniques were analyzed for ammonia, nitrite, nitrite plus nitrate, total nitrogen, orthophosphate, and total phosphorus by the USGS National Water Quality Laboratory with methods described in Fishman (1993). Samples were also analyzed for total suspended sediment by the USGS Sediment Laboratory (Louisville, Kentucky) using standard methods described by Guy (1969). Turbidity of the two different samples was also analyzed onsite using an optical turbidimeter. Each turbidity sample was measured five times and the median value was recorded.

\section{Techniques for Collecting Discrete Samples of Suspended Sediment}

During the July 30, 2009, and August 12, 2009, sampling events, discrete sampling of the water column for suspended sediment was performed in conjunction with ADCP backscatter measurements. A Van Dorn sampler was used to collect discrete water samples at 10 depths $(3.5,7.5,11,14,15.5$, $17.5,19.5,20.5,22$, and $24.5 \mathrm{ft}$ below the water surface) along two vertical profiles near the center of the Saginaw River near station 04157061 (fig. 3). The left profile (looking downstream) is located at about $43^{\circ} 36^{\prime} 33.6^{\prime \prime}$ north latitude and $83^{\circ} 53^{\prime} 11.7^{\prime \prime}$ " west longitude; the right profile is located at about $43^{\circ} 36^{\prime} 32.8^{\prime \prime}$ north latitude and $83^{\circ} 53^{\prime} 10.9^{\prime \prime}$ "west longitude. The Van Dorn sampler was field-rinsed with river water prior to, and in between, discrete water samples. Sample water collected from the Van Dorn sampler was shaken to homogenize the sample and then decanted directly into a suspended-sediment sample bottle. All sediment bottles were then processed, stored, and shipped according to USGS protocols (Wilde, 2006). 


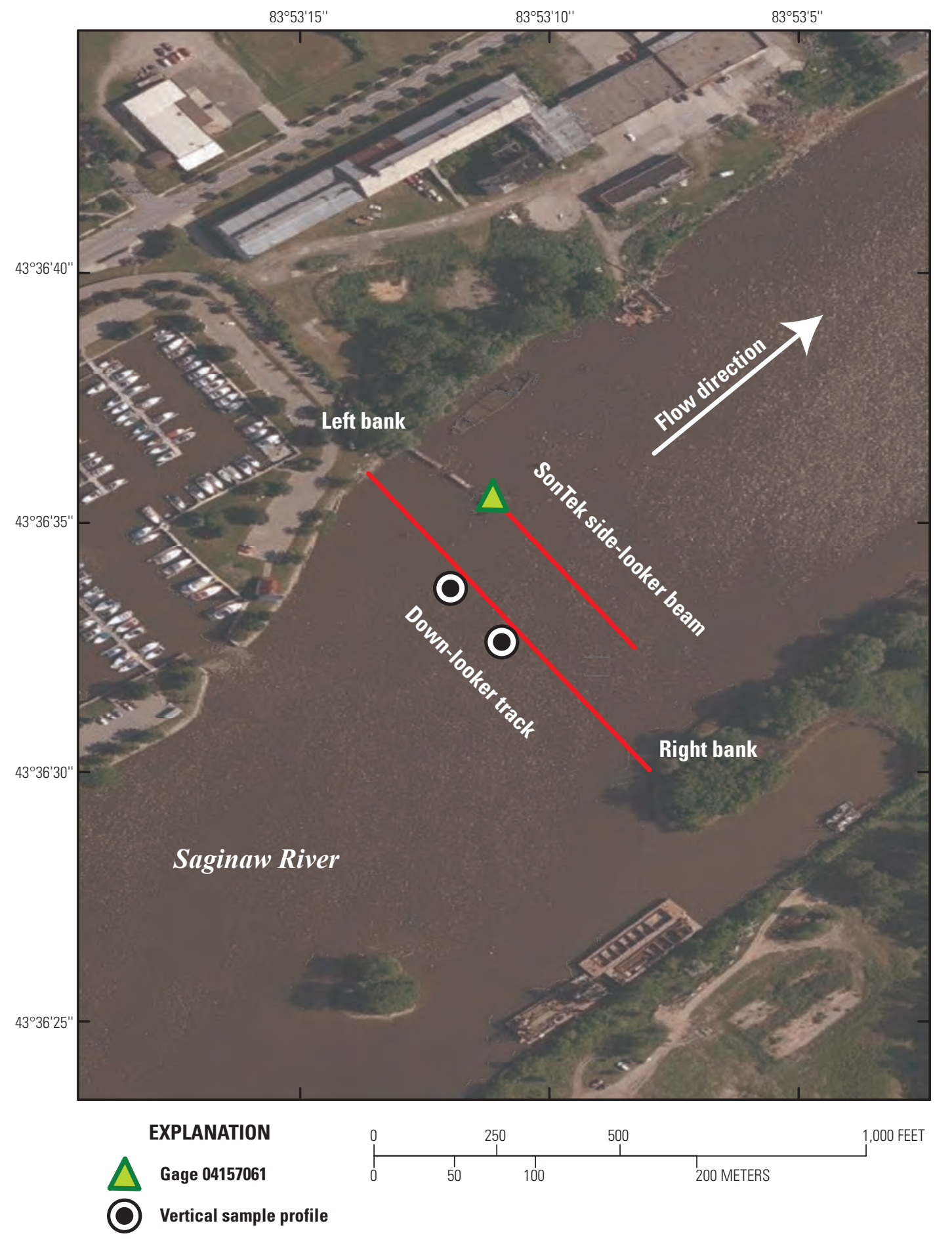

Figure 3. Discrete suspended-sediment sampling locations near station 04157061, Saginaw River at Bay City, Michigan. 


\section{Gaged-Flow Comparison}

The gaged flows for the Saginaw River at Saginaw (04157000) and at Bay City (04157061) display similar characteristics from April 20, 2009 to September 9, 2009. Figure 4 illustrates the daily mean flow values for both gages as well as the underlying unit flow values (instantaneous flow values recorded at every 15 or fewer minute intervals) that were used to compute the daily mean flow value. The daily mean flow value was computed as the average of all unit flow values recorded in 1 day. Precipitation data collected at National Weather Service (NWS) Cooperative Observer Program stations in Saginaw, Mich. (station 207222, fig. 1) and Essexville, Mich. (station 202631, fig. 1) are also included (National Oceanic and Atmospheric Administration, 2010). The general magnitude and distribution of the daily mean flow values at both stations match relatively well, indicating the flows are generally associated with precipitation events; this can be seen for the events in early May, mid-June, and early August of 2009. There are periods of time where the daily mean flow at Saginaw is estimated (grey background on fig. 4) in which there are substantial differences in daily mean flow between the two gages.

Comparison of the daily mean flow values between the Saginaw and Bay City gages indicates that the flows at Saginaw are generally higher than the flows measured in Bay City. Figure 5 illustrates the residual of the daily mean flow between the two gages (daily mean flow value at Saginaw minus the daily mean flow value at Bay City) through the period when both sites were gaged. Ninety-nine of the 139 coincident daily mean flow values were higher at Saginaw than Bay City. Presenting the residuals as a relative percent difference of the flow (absolute value of the residual divided by the average of the flow at Saginaw and Bay City gages) shows that the percent difference in flow is greatest during periods of low flows. Although this is expected because the residual is larger relative to the total flow during low flow, it suggests that the greatest disagreement in flows between the two gages is during low flows. As a whole, the median and mean relative percent differences were 13.7 and 18.4 percent respectively (fig. 5).

The decrease in flow from the upstream gage to the downstream gage was not expected, because some small tributaries between Saginaw and Bay City contribute flow to the Saginaw River. Investigation into whether water withdrawals from the Saginaw River accounted for this flow reduction revealed that more water was discharged to the river as a result of various manufacturing and water treatment processes than was withdrawn from the river (Andrew LeBaron and Dawn Roush, Michigan Department of Natural Resources and Environment, written commun., 2010). Return flow to the river from various manufacturing and treatment facilities ranged from less than 1 percent to almost 7 percent of the daily mean flow at Saginaw and averaged 1.2 percent from April 20 to September 9, 2010. This water use information further confounded the results of the comparison of the gages. Upon closer inspection of the unit values, it became clear that significant backwater and, in some cases, reverse flow was occurring at the streamflow-gaging stations; however, this complex flow was not able to be resolved by the traditional stage-discharge technique utilized at the upstream station at Saginaw (fig. 4).

The ability to record backwater and reverse-flow conditions at the Bay City gage but not at the Saginaw gage was a result of the different technologies used for gaging at each site. The ADCP gage at Bay City instantaneously measured both the magnitude and direction of the water velocity in the river. By using the index-velocity relation developed for that gage, a discharge value could be estimated. During periods of backwater or reverse flow, the index velocity allowed for the estimation of a negative discharge to be estimated as seen on figure 4.

At the gage in Saginaw, only the instantaneous river stage was being measured. The instantaneous stage was then used to estimate the flow by using the stage-discharge relation developed for that gage. The nature of the stage-discharge relation was such that a negative flow could not be computed. Therefore, when the measured instantaneous stage was affected by backwater or reverse-flow conditions, a flow of zero was recorded. If a flow of zero was recorded for a unit value, then the daily mean flow value was not computed from the unit values but was estimated (fig. 4 , shaded gray) as the combined flow of the four major tributaries (Cass, Flint, Shiawassee and Tittabawassee Rivers) to the Saginaw River. These flows come from gages that are upstream of the Saginaw gage, which contributes to the uncertainty associated with the flow estimate at Saginaw.

The complex flow dynamics of the Saginaw River pose problems for gaging stations utilizing traditional stage-discharge monitoring techniques. Conversely, gaging stations that use acoustic technology are able to estimate flow under the range of conditions observed on the Saginaw River because river velocity is directly measured at these stations. Converting gaging stations on the Saginaw River from stage-discharge stations to acoustic stations would likely improve the flow estimates along the river. In turn, because constituent loads to Saginaw Bay are calculated using Saginaw River flow data from station 04157000 , the constituent load estimates would likely be improved as well. 


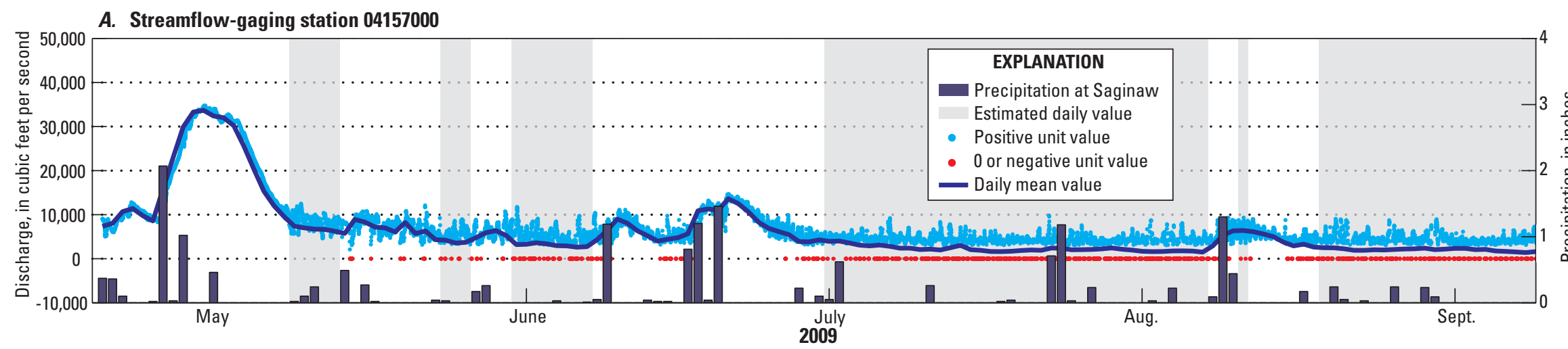

B. Streamflow-gaging station 04157061

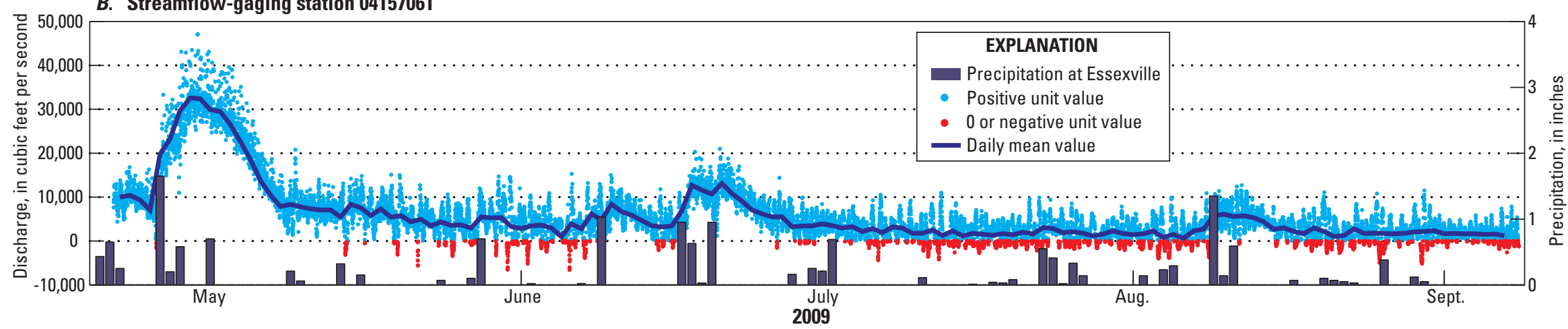

Figure 4. Daily mean and unit flows at $A$, station 04157000, Saginaw River at Saginaw, and B, station 04157061, Saginaw River at Bay City, Michigan from April to September 2009. 

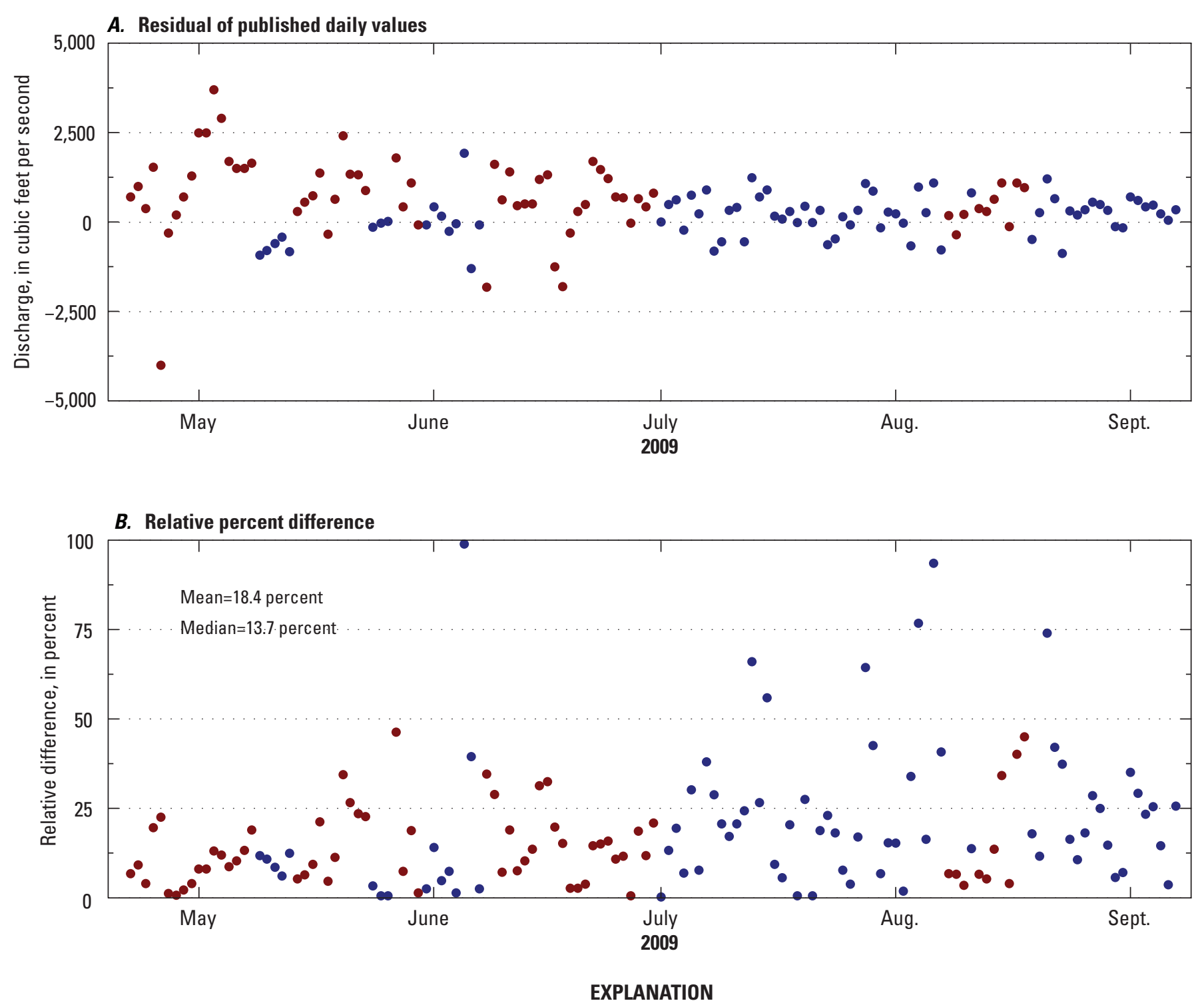

- Flow estimated at 04157000

- Flow computed at 04157000

Figure 5. A, residual for daily mean flows between stations 04157000, Saginaw River at Saginaw, and 04157061, Saginaw River at Bay City, Michigan, and $B$, the relative percent difference of daily mean flows for the two stations. 


\section{Water Quality Results}

In total, 16 paired surface grab and DIMV samples were collected on the Saginaw River. The results of the physical and chemical analyses for these samples are illustrated in tables 1-3.

Differences in concentrations of the paired samples resulting from sampling technique were tested for using the Wilcoxon signed-rank test (Helsel and Hirsch, 2002). This test was selected because it was not sensitive to the distribution of the data, which was not normally distributed. Standard parametric tests, such as the paired t-test, require a normal distribution to detect true differences in the means of two sample populations (Helsel and Hirsch 2002). The null hypothesis was that the median constituent concentration for each sample population (grab and integrated) was the same. The Wilcoxon signed-rank test was applied to each site individually as well as for both sites combined. All differences in medians with levels of significance at 5 percent or lower $(p<0.05)$ were considered statistically significant. In the event a constituent concentration was censored, a value of one-half the censoring level was substituted for the censored value for the purpose of performing the test.

Statistical differences in paired-sample median concentrations were detected for four different constituents (table 4). Nitrite plus nitrate, suspended sediment, total phosphorus, and turbidity were statistically different on the basis of sampling technique at station number 04156999 (upstream). Suspended sediment, total phosphorus, and turbidity were also statistically different at station number 04157061 (downstream) as well as when data from both sites were combined (table 4).

In general, the constituent concentrations that were significantly different were greater in the DIMV samples than in the surface-grab samples. Previous studies have shown suspended-sediment, turbidity, and constituent concentrations associated with suspended material, such as total phosphorus, are affected by the sampling technique employed to collect

Table 1. Physical parameters measured at stations 04156999, Saginaw River at Saginaw, and 04157061, Saginaw River at Bay City, Michigan.

$\left[\mathrm{ft}^{3} / \mathrm{s}\right.$, cubic feet per second; $\mathrm{mg} / \mathrm{L}$, milligrams per liter; $\mu \mathrm{S} / \mathrm{cm}$, microsiemens per centimeter; $\mathrm{C}^{\circ}$, degrees Celsius; NA, not available]

\begin{tabular}{lccccc}
\hline \multicolumn{1}{c}{ Date } & $\begin{array}{c}\text { Flow } \\
\left(\mathbf{f t}^{3} \mathbf{s}\right)\end{array}$ & $\begin{array}{c}\text { Dissolved } \\
\mathbf{0 x y g e n} \\
(\mathbf{m g} / \mathbf{L})\end{array}$ & $\mathbf{p H}$ & $\begin{array}{c}\text { Specific } \\
\mathbf{c o n d u c t a n c e} \\
(\boldsymbol{\mu S} / \mathbf{c m})\end{array}$ & $\begin{array}{c}\text { Water } \\
\text { temperature } \\
\left(\mathbf{C}^{\circ}\right)\end{array}$ \\
\hline Apr. 21, 2009 & NA & 10.7 & 8.1 & 619 & 9.7 \\
May 18, 2009 & 6,940 & 8.9 & 8.2 & 615 & 15.9 \\
June 16, 2009 & 3,500 & 8.1 & 8.0 & 668 & 21.5 \\
July 14, 2009 & 3,960 & 10.7 & 8.4 & 748 & 23.6 \\
July 30, 2009 & 2,060 & 7.5 & 8.0 & 691 & 24.2 \\
Aug. 12, 2009 & 6,530 & 6.2 & 7.5 & 540 & 24.9 \\
Sept. 2, 2009 & 814 & 9.8 & 6.8 & 689 & 19.7 \\
Sept. 8, 2009 & 1,030 & 12.1 & 8.3 & 731 & 23.0 \\
\hline & & Station 04157061 & & \\
\hline Apr. 21, 2009 & 8,700 & 9.5 & 8.2 & 664 & 10.8 \\
May 18, 2009 & 8,460 & 8.4 & 8.1 & 558 & 15.1 \\
June 16, 2009 & 1,340 & 7.6 & 7.8 & 616 & 20.6 \\
July 14, 2009 & -247 & 7.8 & 8.1 & 676 & 22.5 \\
July 30, 2009 & 2,130 & 7.7 & 8.0 & 670 & 23.5 \\
Aug. 12, 2009 & 8,260 & 5.4 & 6.8 & 484 & 24.5 \\
Sept. 2, 2009 & -40.1 & 7.7 & 8.0 & 671 & 20.7 \\
Sept. 8, 2009 & 4,440 & 10.0 & 8.1 & 691 & 21.8 \\
\hline
\end{tabular}


a sample (Horowitz and others, 1990; Martin and others, 1992; Harmel and others, 2010). Median values of the relative percent difference for constituent concentration on the basis of sampling technique are shown in table 5. As expected, suspended-sediment concentrations showed the highest variability between surface-grab and DIMV sampling techniques. The median relative percent difference ranged from 27 percent at station 04156999 to 40 percent at station 04157061. The median relative percent difference when combining data from both stations was 37 percent (table 5). Turbidity also had high variability between the sampling techniques, with median relative percent differences ranging from 19 percent at station 04156999 to 28 percent at station 04157061 and 26 percent when combined (table 5). Variability in total phosphorus concentration was smaller, with median relative percent differences ranging from 7.4 at station 04157061 to 12 at station 04156999 and 9.7 percent when combined.

The statistically significant difference between nitrite plus nitrate concentrations due to sampling technique at station 04156999 was unexpected. Variability in nitrite plus nitrate concentration was small, with median relative percent differences ranging from 0.8 percent at station 04157061 to 2.3 percent at station 04156999 and 1 percent when combined.
However, results by Harmel and others (2010) indicate that dissolved species like nitrite plus nitrate may vary across a channel. It is uncertain in this case why the significant difference in concentration is occurring at this station. Nitrite values are nearly identical for both sampling techniques (table 2), which indicates that the nitrate component is contributing to the variation in concentration due to the sampling technique used. Possible explanations for the variation include nearby point sources of nitrate discharge that have not fully mixed within the channel or algal activity in the photic zone of the channel. Algae may be utilizing nitrate in the upper portion of the channel that is targeted by surface-grab sampling, causing nitrate concentrations to be lower there than in deeper parts of the channel, although other dissolved nutrient constituents commonly utilized for algal growth did not exhibit this distribution.

Generally, concentrations of suspended material were lower at station 04157061 than at station 04156999 (table 2 and 3). Although constituent concentrations were lower at station 04157061 , the variability in constituent concentration as a result of the sampling technique used was greater than at station 04156999 (table 5). The greater median relative percent difference at the station 04157061 indicates that the system

Table 2. Summary of nutrient and sediment concentrations measured at station 04156999, Saginaw River at Saginaw, Michigan.

[DIMV, Depth Integrated Multiple Vertical; NTRU, Nephelometric Turbidity Ratio Unit; mg/L, milligrams per liter; N, Nitrogen; P, Phosphorus; <, value censored at minimum reporting level; E, value estimated above method detection level but below minimum reporting level; <, less than]

\begin{tabular}{llllcccccc}
\hline \multicolumn{1}{c}{ Date } & $\begin{array}{c}\text { Sample } \\
\text { type }\end{array}$ & $\begin{array}{c}\text { Turbidity } \\
\text { (NTRU) }\end{array}$ & $\begin{array}{c}\text { Ammonia } \\
\text { (mg/L as N) }\end{array}$ & $\begin{array}{c}\text { Nitrite }+ \\
\text { nitrate } \\
\text { (mg/L as N) }\end{array}$ & $\begin{array}{c}\text { Nitrite } \\
\text { (mg/L as N) }\end{array}$ & $\begin{array}{c}\text { Orthophosphate } \\
\text { (mg/L as P) }\end{array}$ & $\begin{array}{c}\text { Total } \\
\text { phosphorus } \\
\text { (mg/L as P) }\end{array}$ & $\begin{array}{c}\text { Total } \\
\text { nitrogen } \\
\text { (mg/L as N) }\end{array}$ & $\begin{array}{c}\text { Suspended } \\
\text { sediment } \\
\text { (mg/L) }\end{array}$ \\
\hline Apr. 21, 2009 & DIMV & 32.4 & 0.068 & 1.32 & 0.012 & $E 0.009$ & 0.098 & 2.15 & 46.0 \\
Apr. 21, 2009 & Grab & 33.8 & .081 & 1.30 & .012 & .010 & .095 & 2.02 & 39.0 \\
May 18, 2009 & DIMV & 21.7 & .023 & 1.20 & .014 & .016 & .077 & 1.99 & 26.0 \\
May 18, 2009 & Grab & 17.9 & .118 & 1.17 & $<.002$ & .017 & .069 & 1.96 & 22.0 \\
\hline June 16, 2009 & DIMV & 13.5 & $<.020$ & 2.14 & .029 & .016 & .065 & 2.75 & 26.0 \\
June 16, 2009 & Grab & 9.29 & $<.020$ & 2.12 & .028 & .015 & .053 & 2.79 & 8.0 \\
\hline July 14, 2009 & DIMV & 21.1 & $<.020$ & .929 & .011 & E.006 & .069 & 1.60 & 25.0 \\
\hline July 14, 2009 & Grab & 14.6 & $<.020$ & .893 & .011 & E.006 & .057 & 1.57 & 14.0 \\
\hline July 30, 2009 & DIMV & 15.6 & $<.020$ & 1.03 & .015 & .024 & .074 & 1.62 & 16.0 \\
\hline July 30, 2009 & Grab & 13.1 & $<.020$ & 1.00 & .014 & .024 & .073 & 1.66 & 13.0 \\
\hline Aug. 12, 2009 & DIMV & 30.2 & E.020 & .950 & .022 & .032 & .111 & 1.61 & 36.0 \\
Aug. 12, 2009 & Grab & 24.9 & .025 & .968 & .022 & .033 & .098 & 1.59 & 28.0 \\
\hline Sept. 2, 2009 & DIMV & 19.8 & $<.020$ & .562 & .007 & .012 & .060 & 1.04 & 21.0 \\
\hline Sept. 2, 2009 & Grab & 7.54 & $<.020$ & .487 & .007 & .012 & .045 & .975 & 6.0 \\
\hline Sept. 8, 2009 & DIMV & 20.0 & $<.020$ & .393 & .008 & $<.024$ & .066 & 1.10 & 20.0 \\
\hline Sept. 8, 2009 & Grab & 17.5 & $<.020$ & .393 & .009 & $<.024$ & .071 & 1.14 & 15.0 \\
\hline
\end{tabular}


Table 3. Summary of nutrient and sediment concentrations measured at station 04157061, Saginaw River at Bay City, Michigan.

[DIMV, Depth Integrated Multiple Vertical; NTRU, Nephelometric Turbidity Ratio Unit; mg/L, milligrams per liter; N, Nitrogen; P, Phosphorus; E, value estimated above method detection level but below method reporting level]

\begin{tabular}{llcccccccc}
\hline \multicolumn{1}{c}{ Date } & $\begin{array}{c}\text { Sample } \\
\text { type }\end{array}$ & $\begin{array}{c}\text { Turbidity } \\
\text { (NTRU) }\end{array}$ & $\begin{array}{c}\text { Ammonia } \\
\text { (mg/L as N) }\end{array}$ & $\begin{array}{c}\text { Nitrite }+ \\
\text { nitrate } \\
\text { (mg/L as N) }\end{array}$ & $\begin{array}{c}\text { Nitrite } \\
\text { (mg/L as N) }\end{array}$ & $\begin{array}{c}\text { Orthophosphate } \\
\text { (mg/L as P) }\end{array}$ & $\begin{array}{c}\text { Total } \\
\text { phosphorus } \\
\text { (mg/L as P) }\end{array}$ & $\begin{array}{c}\text { Total } \\
\text { nitrogen } \\
\text { (mg/L as N) }\end{array}$ & $\begin{array}{c}\text { Suspended } \\
\text { sediment } \\
\text { (mg/L) }\end{array}$ \\
\hline Apr. 21, 2009 & DIMV & 22.4 & 0.092 & 1.25 & 0.013 & 0.010 & 0.076 & 1.94 & 22.0 \\
Apr. 21, 2009 & Grab & 19.0 & .104 & 1.24 & .013 & .011 & .068 & 1.83 & 18.0 \\
May 18, 2009 & DIMV & 20.1 & .039 & 1.19 & .017 & .017 & .075 & 2.02 & 23.0 \\
May 18, 2009 & Grab & 17.3 & .040 & 1.20 & .017 & .018 & .072 & 1.96 & 18.0 \\
\hline June 16, 2009 & DIMV & 15.5 & .031 & 2.78 & .053 & .009 & .071 & 3.65 & 15.0 \\
\hline June 16, 2009 & Grab & 11.1 & E.016 & 2.80 & .053 & .008 & .066 & 3.72 & 10.0 \\
\hline July 14, 2009 & DIMV & 25.5 & .083 & .922 & .022 & .016 & .085 & 1.68 & 29.0 \\
\hline July 14, 2009 & Grab & 12.3 & .067 & .922 & .022 & .014 & .070 & 1.72 & 10.0 \\
\hline July 30, 2009 & DIMV & 14.1 & E.011 & .938 & .027 & .011 & .075 & 1.63 & 16.0 \\
\hline July 30, 2009 & Grab & 10.7 & E.015 & .953 & .027 & .012 & .074 & 1.65 & 9.00 \\
\hline Aug. 12, 2009 & DIMV & 20.2 & .040 & .848 & .024 & .039 & .113 & 1.48 & 21.0 \\
\hline Aug. 12, 2009 & Grab & 15.9 & .034 & .840 & .025 & .038 & .104 & 1.45 & 14.0 \\
\hline Sept. 2, 2009 & DIMV & 16.2 & .061 & .718 & .021 & .020 & .077 & 1.32 & 16.0 \\
\hline Sept. 2, 2009 & Grab & 11.5 & .054 & .716 & .022 & .020 & .067 & 1.36 & 10.0 \\
\hline Sept. 8, 2009 & DIMV & 13.5 & .073 & .471 & .015 & .036 & .065 & 1.17 & 14.0 \\
\hline Sept. 8, 2009 & Grab & 10.1 & .069 & .467 & .015 & E.014 & .061 & 1.11 & 10.0 \\
\hline
\end{tabular}

Table 4. Results of use of the Wilcoxon two-sided signed-ranks test to compare paired depth integrated multiple vertical and surface-grab samples for selected constituents collected at collected at station 04156999, Saginaw River at Saginaw, and 04157061,Saginaw River at Bay City, Michigan and for both stations combined.

\begin{tabular}{lccc}
\hline \multirow{2}{*}{ Constituent } & \multicolumn{3}{c}{ p-value } \\
\cline { 2 - 4 } & Station 04156999 & Station 04157061 & Both stations \\
\hline Ammonia & 10.10 & 0.25 & 10.92 \\
Nitrite & .46 & .94 & .46 \\
Nitrite plus nitrate & .035 & .67 & .097 \\
Orthophosphate & 1.26 & .25 & .80 \\
Suspended sediment & .0078 & .014 & .0005 \\
Total nitrogen & .74 & .74 & .53 \\
Total phosphorus & .039 & .0078 & .0004 \\
Turbidity & .021 & .014 & .0006 \\
\hline
\end{tabular}

\footnotetext{
1. 10 percent or more values are censored.
} 
Table 5. Median relative percent difference for selected constituents in depth integrated multiple vertical and surface-grab samples collected at stations 04156999, Saginaw River at Saginaw, and 04157061, Saginaw River at Bay City, Michigan and for both stations combined.

\begin{tabular}{lccc}
\hline \multicolumn{1}{c}{ Constituent } & Station $\mathbf{0 4 1 5 6 9 9 9}$ & Station $\mathbf{0 4 1 5 7 0 6 1}$ & Both stations \\
\hline Ammonia & 10 & 15 & ${ }^{1} 13$ \\
Nitrite & 1.9 & 0.3 & 1.2 \\
Nitrite plus nitrate & 2.3 & 0.8 & 1.0 \\
Orthophosphate & 12.7 & 9.4 & 3.4 \\
Suspended sediment & 27 & 40 & 37 \\
Total nitrogen & 2.0 & 2.5 & 2.2 \\
Total phosphorus & 12 & 7.4 & 9.7 \\
Turbidity & 19 & 28 & 26 \\
\hline
\end{tabular}

1. 10 percent or more values are censored.

may not be well mixed. The complex interaction of the Saginaw River and Saginaw Bay, near station 04157061, likely leads to velocity variations that affect the concentrations of suspended material. As a result, the DIMV sampling technique was better able to characterize the suspended-material concentration than the grab sampling technique, because the DIMV technique allows river water to be composited both laterally and vertically to account for velocity variations throughout the channel.

Total phosphorus concentrations did not exhibit the same characteristics as the other suspended-material constituents. Even though there was statistically significant variation in the total phosphorus concentration as a result of sampling technique (table 4 ), the median relative percent difference was less at station 04157061 (7.4 percent) than at station 04156999 (12 percent). In addition, the median total phosphorus concentration of DIMV samples was higher at station 04157061 $(0.075 \mathrm{mg} / \mathrm{L})$ than at station $04156999(0.071 \mathrm{mg} / \mathrm{L})$. This may indicate that the dissolved species of phosphorus were a larger percentage of the total phosphorous at station 04157061 than at station 04156999 . To explore that possibility, the percentage of total phosphorus that was dissolved was estimated by dividing the concentration of orthophosphate by the total phosphorous concentration. The mean percentage of orthophosphate for station 04156999 was 20 percent whereas the mean for station 04157061 was 25 percent. This is a slight increase that does not take into account all dissolved species of phosphorous, so some uncertainty remains as to whether differences in the amount of dissolved phosphorus between sites is leading to the variability between sites.

In sum, variations in constituent concentration were detected as a result of the sampling technique used at two stations on the Saginaw River. DIMV samples better characterized suspended constituents that are heterogeneously distributed laterally and vertically throughout the river channel and, in some cases, dissolved constituents than surface-grab samples. Ideally, more samples would have been collected over a larger suite of flows and a larger time period. This would have improved sample size for the statistical tests, demonstrated how large-magnitude flows may affect heterogeneity of constituent concentrations in the river channel, and improved understanding of the temporal distribution of constituent concentrations in the river. Even so, the variability in constituent concentration due to sampling technique has implications for the estimation of loads to Saginaw Bay, specifically for constituents associated with particulate material in the river like suspended sediment and total phosphorous. Discrete surface-grab sampling may introduce bias that underestimates the concentrations of sediment between 27 and 40 percent and total phosphorus between 7.4 and 12 percent. Therefore load estimates based on constituent concentrations that are biased low will also be biased low. 


\section{Suspended Sediment and Acoustic Backscatter Results}

An ADCP measures water velocity using the Doppler principal (Simpson, 2001). While it is submerged in water, an ADCP emits an ultrasonic (acoustic frequencies greater than $20 \mathrm{kHz}$ ) pulse through two or more transducers. The same transducers are then used to detect the returning sound waves that have bounced off suspended-sediment particles, plankton, or other pulse-reflecting bodies or backscatterers moving with the water. The slight shift in frequency or phase between the emitted and returned signal is used to compute water velocity in two or more dimensions.

The returning acoustic signal is commonly discretized over time to compute water velocities at varying distance intervals (bins of uniform size) from the ADCP. If the ADCP transducers are oriented vertically downward from a point near the water surface, this discretization will provide velocity information with increasing depth at that point. If the ADCP is oriented horizontally in the water column, the discretization will provide velocity information at that depth for increasing distances across a river. The maximum distance from the ADCP for which velocity data can be obtained may be limited by the distance to the channel bottom or to the opposite channel bank or by the strength of the returning acoustic signal. The strength of the returning signal is reduced with distance between the ADCP and the bin and when fewer backscatterers are in the water.

In addition to water-velocity data, Deines (1999) describes calibration procedures for the use of vertical profiles of acoustic-backscatter data to estimate suspended plankton and sediment concentrations in water. Thorne and others (1991) conclude that acoustic-backscatter techniques are potentially powerful tools for examining the structure of suspended-sediment concentration profiles near the sea bed. Gartner (2004) describes successfully estimating suspendedsolids concentrations from acoustic-backscatter intensity measured by ADCP in San Francisco Bay, California.

Preliminary assessments of the potential utility of acoustic backscatter as an indicator of suspended-sediment concentrations were conducted on the Saginaw River near streamflow-gaging station 04157061 (fig. 3). In the first assessment, detection of the variation of suspended-sediment concentrations with depth by use of acoustic backscatter was investigated. A down-looking boat-mounted ADCP unit was held, approximately stationary over two vertical profiles while water samples were collected at various depths and subsequently measured for suspended-sediment concentrations. In the second assessment, a side-looking (horizontal) ADCP (HADCP) unit was used to track temporal variations in flow velocity and backscatter across the river from April 21 to September 8, 2009. Preliminary results for both investigations are provided below.

\section{Detecting Vertical Variations in Point Measurements of Suspended Sediment Concentrations with Down-Looking Acoustic Backscatter Data}

Suspended sediment concentrations were measured in water samples taken at 10 depths along two vertical profiles near the center of the Saginaw River at streamflow-gaging station 04157061 (fig. 3). The left profile (looking downstream) is located at about $43^{\circ} 36^{\prime} 33.6^{\prime \prime}$ north latitude and $83^{\circ} 53^{\prime} 11.7^{\prime \prime}$ 'west longitude; the right profile is located at about $43^{\circ} 36^{\prime} 32.8^{\prime}$ " north latitude and $83^{\circ} 53^{\prime} 10.9^{\prime}$ " west longitude. Sediment-sampling events occurred on July 30 , and August 12, 2009.

A downward-facing RD Instruments Workhorse Rio Grande ADCP, operating at $600 \mathrm{kHz}$ with four beams, was used to measure water velocity at 1 -second intervals during both sampling events. For each $1.6 \mathrm{ft}$-depth bin, water-velocity and backscatter values were averaged over periods when samples for suspended-sediment analysis were obtained at each profile. These periods were less than 10 minutes long. Binaverage velocity and backscatter data were linearly interpolated from depth bin centers to points of suspended-sediment sample collection. The deepest suspended-sediment samples were matched with the average velocity and backscatter data from the deepest ADCP bin. The results provide water-velocity and acoustic-backscatter data for comparison with suspendedsediment concentrations measured in water samples (table 6).

Substantial changes in flow magnitude and direction can occur over short periods of time at station 04157061, because of the low hydraulic gradient of the river and the proximity of the streamflow-gaging station to Saginaw Bay, where water levels are sensitive to changes in wind velocity. Particularly during the summer months, changes in flow near the station are more commonly associated with wind effects and variable backwater conditions from the bay, compounded by large conveyance characteristics of Saginaw River, rather than changes in runoff conditions in the watershed. Major tributaries to Saginaw River were considered at base flow conditions shortly before and during the sampling events. Ancillary measurements of flow were taken at a transect just downstream from the two profiles, labeled "Down-looker track" in figure 3. Continuous measurements of water levels taken at station 04157061 also show hydrodynamic variations at the time of sample collection (fig. 6).

Sampling depths and acoustic-backscatter characteristics along the transect through the sampling profiles for the July and August sampling events are shown on figure 7 and figure 8. Note that the depth bins for the July 30, 2009 transect taken from 11:01 to 11:05 a.m. (fig. 7) were $0.33 \mathrm{ft}$ in height, whereas the depth bins for the Aug. 12, 2009 transect taken from 11:03 to 11:07 a.m. (fig. 8) were $1.6 \mathrm{ft}$ in height. Depth bins during suspended-sediment sampling were $1.6 \mathrm{ft}$, however, during both sampling events. 
Table 6. Suspended-sediment concentrations and acoustic-backscatter and velocity data from measurements at vertical profiles at station 0415761, Saginaw River at Bay City, Michigan._-Continued

\begin{tabular}{|c|c|c|c|c|c|}
\hline Eastern Standard Time & Transect & $\begin{array}{l}\text { Sample depth below the } \\
\text { water surface, } \\
\text { in feet }\end{array}$ & $\begin{array}{l}\text { Suspended-sediment } \\
\text { concentration, } \\
\text { in milligrams per liter }\end{array}$ & $\begin{array}{l}\text { Interpolated acoustic } \\
\text { backscatter, } \\
\text { in decibels }\end{array}$ & $\begin{array}{l}\text { Interpolated velocity, } \\
\text { in feet per second }\end{array}$ \\
\hline \multicolumn{6}{|c|}{ July 30, 2009} \\
\hline 10:15 a.m. & Right & 24.5 & 16.0 & 74.8 & 0.11 \\
\hline 10:17 a.m. & & 20.5 & 15.0 & 74.6 & .11 \\
\hline 10:18 a.m. & & 19.5 & 14.0 & 74.2 & .11 \\
\hline 10:19 a.m. & & 17.5 & 14.0 & 74.0 & .11 \\
\hline 10:20 a.m. & & 15.5 & 13.0 & 73.4 & .12 \\
\hline 10:23 a.m. & & 7.5 & 10.0 & 73.8 & .23 \\
\hline 10:24 a.m. & & 3.5 & 10.0 & 72.2 & .30 \\
\hline 10:37 a.m. & Left & 24.5 & 21.0 & 78.3 & .10 \\
\hline 10:38 a.m. & & 22.0 & 16.0 & 77.6 & .10 \\
\hline 10:39 a.m. & & 20.5 & 17.0 & 76.5 & .09 \\
\hline 10:40 a.m. & & 19.5 & 15.0 & 76.2 & .09 \\
\hline 10:41 a.m. & & 17.5 & 14.0 & 75.3 & .14 \\
\hline \multicolumn{6}{|c|}{ August 12, 2009} \\
\hline 11:28 a.m. & Right & 24.5 & 140.0 & 80.7 & 0.82 \\
\hline 11:29 a.m. & & 22.0 & 23.0 & 81.3 & .78 \\
\hline 11:30 a.m. & & 20.5 & 24.0 & 81.6 & .76 \\
\hline 11:31 a.m. & & 19.5 & 26.0 & 81.4 & .77 \\
\hline 11:32 a.m. & & 17.5 & 23.0 & 81.1 & .78 \\
\hline 11:33 a.m. & & 15.5 & 20.0 & 80.8 & .79 \\
\hline 11:34 a.m. & & 14.0 & 21.0 & 80.5 & .80 \\
\hline 11:35 a.m. & & 11.0 & 20.0 & 80.2 & .82 \\
\hline 11:36 a.m. & & 7.5 & 23.0 & 80.0 & .81 \\
\hline 11:37 a.m. & & 3.5 & 17.0 & 76.7 & .81 \\
\hline
\end{tabular}


Table 6. Suspended-sediment concentrations and acoustic-backscatter and velocity data from measurements at vertical profiles at station 0415761, Saginaw River at Bay City, Michigan._-Continued

\begin{tabular}{|c|c|c|c|c|c|}
\hline 11:48 a.m. & Left & 24.5 & 24.0 & 83.3 & .78 \\
\hline 11:49 a.m. & & 22.0 & 26.0 & 83.0 & .81 \\
\hline 11:51 a.m. & & 19.5 & 23.0 & 82.1 & .88 \\
\hline 11:52 a.m. & & 17.5 & 21.0 & 81.6 & .91 \\
\hline 11:53 a.m. & & 15.5 & 26.0 & 81.2 & .93 \\
\hline 11:54 a.m. & & 14.0 & 21.0 & 81.0 & .94 \\
\hline 11:57 a.m. & & 3.5 & 14.0 & 77.2 & .93 \\
\hline
\end{tabular}

${ }^{1}$ Suspended sediment concentration considered an outlier in linear regression with backscatter as the explanatory variable.

Suspended sediment concentrations from water samples obtained during the July sampling event were approximately normally distributed with mean and standard deviation of 13.8 and $2.71 \mathrm{mg} / \mathrm{L}$, respectively. In particular, the Lilliefors test (Conover, 1980) did not reject the null hypothesis of normality at the 5-percent level of significance (p-value 0.0500$)$. In contrast, normality of suspended-sediment concentrations in water samples collected in profiles on Aug. 12, 2009, (August sampling event) was rejected (p-value 0.0066). If the maximum concentration of $40 \mathrm{mg} / \mathrm{L}$ measured in water sampled at $24.5 \mathrm{ft}$ below the water surface in the right profile were excluded, however, the hypothesis of normality was not rejected ( $\mathrm{p}$-value 0.0939 ).

The mean and standard deviations of the 19 nonexcluded suspended-sediment concentrations measured in water obtained during the August sampling event were 22.2 and $3.22 \mathrm{mg} / \mathrm{L}$, respectively. With or without the excluded August concentration of $40.0 \mathrm{mg} / \mathrm{L}$, the equality of the median suspended-sediment concentrations from the July sampling (13.5 mg/L) and August sampling (23.0 mg/L) was rejected ( $\mathrm{p}$-value $<0.0001$ ). No significant differences were found in median suspended-sediment concentrations between profiles during the July sampling event $(p$-value $=0.6472$ ) or the August sampling event $(\mathrm{p}$-value $=0.7605)$.

Because of the relation of suspended sediment to streamflow, time series of suspended-sediment concentration data tend to be asymmetrically (commonly log-normally) distributed, rather than normally distributed. Less information is available about the probability distribution of spatial series of suspended-sediment concentrations along vertical profiles. The normality of suspended-sediment concentration distributions was accepted for the limited range of sediment concentrations available for the analysis described in this report.

Adjusting acoustic-backscatter measurements to relate to suspended-sediment concentrations is not a straightforward process (Gartner, 2004). In particular, acoustic-backscatter values are affected by numerous factors other than suspended particles including transmission losses. These losses are associated with sound absorption by water and suspended particles, and beam spreading along the acoustic path. These effects depend on environmental characteristics including the distance between the acoustic signal and the sediment particles, temperature, pressure, and instrument characteristics including power, transducer size, and frequency.

Algorithms within the WinRiver II software (Teledyne RD Instruments, 2011), were used to convert the Received Signal Strength Indicator (RSSI), in counts (labeled as Intensity in WinRiver II), to a relative backscatter in decibels (labeled as Backscatter in WinRiver II). The relative backscatter estimated by the WinRiver II software provides an indication of local (bin) acoustic backscatterers by providing an adjustment for transmission losses. In this report, backscatter will refer to this adjusted backscatter component labeled as Backscatter in WinRiver II.

As with suspended-sediment concentrations, median backscatter and flow velocity varied between the July and August 2009 sampling events. In July, the median backscatter (in the two profiles) was 74.1 decibels, and the median backscatter in August 2009 was 81.1, or about 9.4 percent higher. Similarly, the median velocity in July 2009 was $0.13 \mathrm{ft} / \mathrm{s}$, and the median velocity in August 2009 was $0.82 \mathrm{ft} / \mathrm{s}$. 

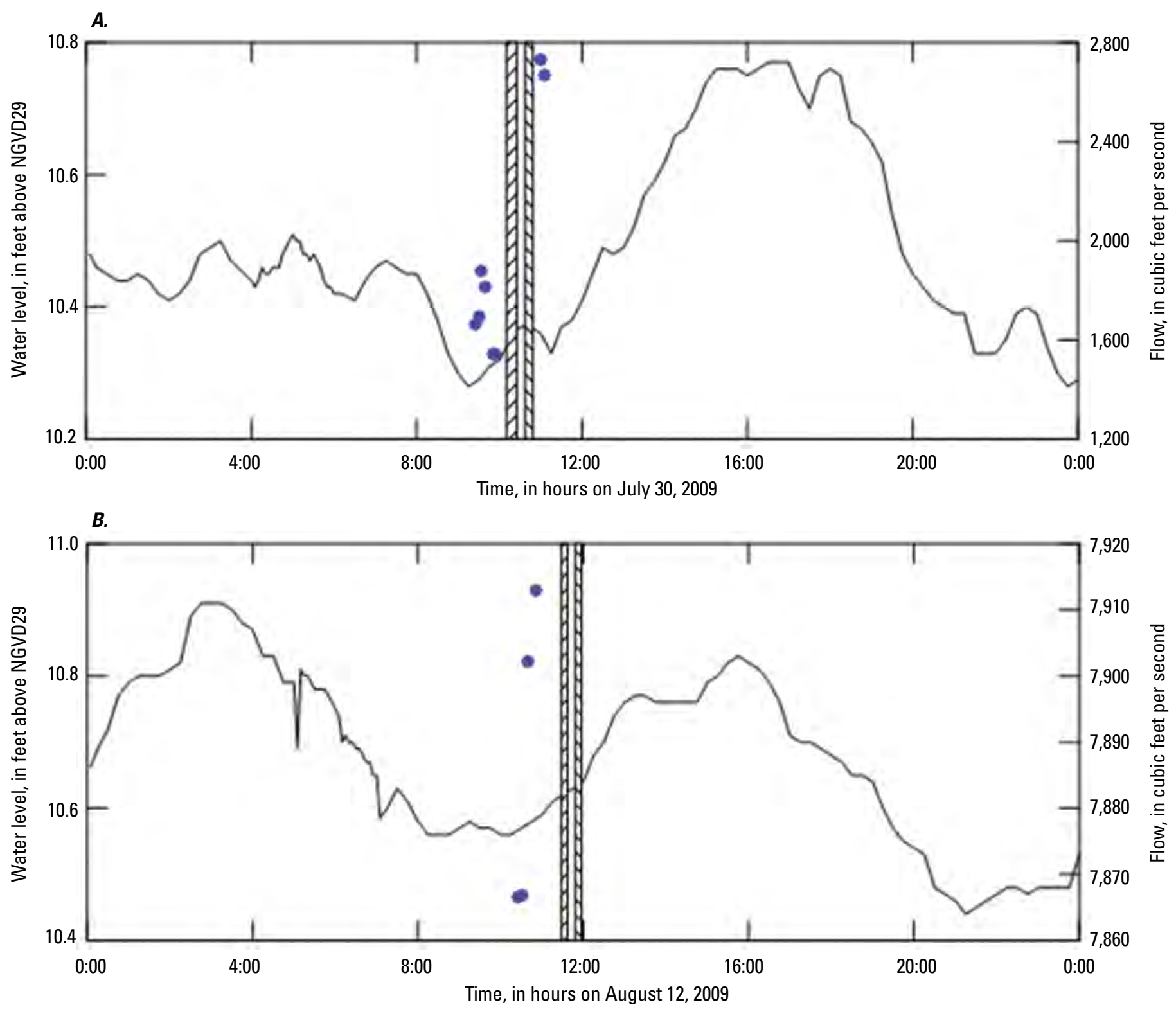

EXPLANATION

$\begin{array}{lll}\text { Water level } & \text { Tा. } & \text { Sampling right profile } \\ \text { Flow } & \text { Tा } & \text { Sampling left profile }\end{array}$

Figure 6. Water levels and flows at station 04157061, Saginaw River at Bay City, Michigan during suspended-sediment sampling on $A$, July 30, 2009, and B, August 12, 2009. 
Based on a Kruskal-Wallis test (Conover, 1980), no significant differences in median backscatter were detected between profiles during the July sampling event ( $p$-value $=0.4961$ ) or during the August sampling event ( $\mathrm{p}$-value $=$ 0.1413 ). No significant differences were found in median velocities between profiles during the July sampling event ( $\mathrm{p}$-value $=0.8796)$. In the August sampling event, however, the median velocity of $0.92 \mathrm{ft} / \mathrm{s}$ in the left profile was somewhat higher than the median velocity of $0.79 \mathrm{ft} / \mathrm{s}$ in the right profile $(\mathrm{p}$-value $=0.0043)$.

Simple linear regression was used to statistically relate acoustic backscatter as the explanatory variate with suspended-sediment concentrations measured from water samples taken along two vertical profiles on Saginaw River at

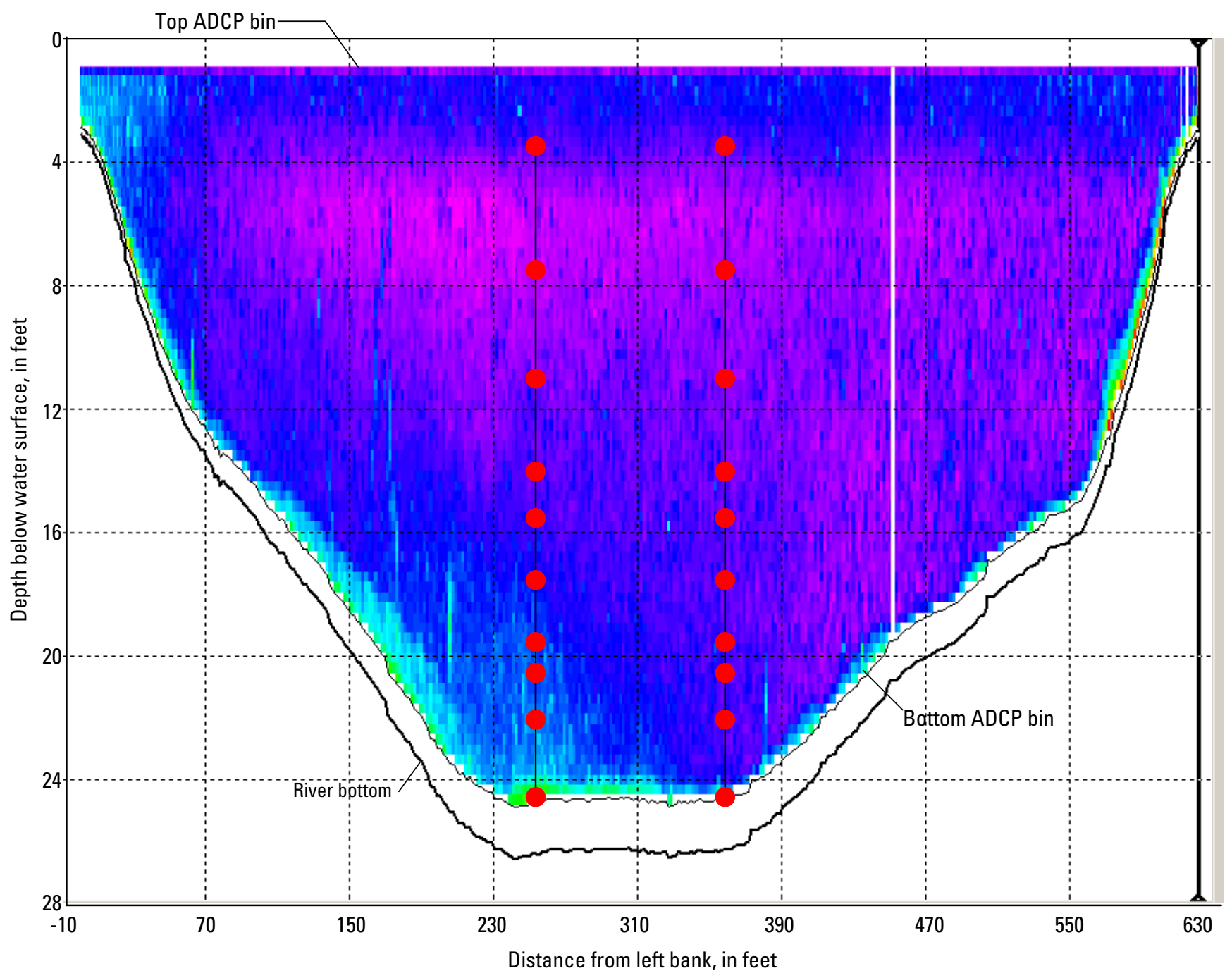

\section{EXPLANATION}

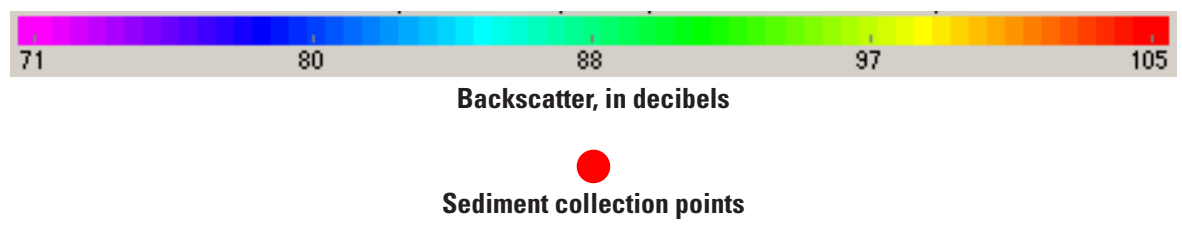

Figure 7. Locations of suspended-sediment concentration measurements along two vertical profiles sampled on July 30, 2009, from 11:01 to 11:05 a.m. at station 04157061, Saginaw River at Bay City, Michigan. (ADCP, acoustic Doppler current profiler) 
Bay City (fig. 9). In an initial regression analysis using all 40 suspended-sediment concentration measurements, the Aug. 12, 2009 , suspended-sediment concentration of $40.0 \mathrm{mg} / \mathrm{L}$ from water in the right profile at a depth of $24.5 \mathrm{ft}$ below the water surface was identified as an outlier based on a studentized residual of 5.325. The root mean square error (RMSE) of this relation was 3.307 and the coefficient of determination $\left(\mathrm{r}^{2}\right)$ was 0.7145 . With this outlier removed, the RMSE decreased to 1.688 while the $\mathrm{r}^{2}$ increased to 0.8933 . In this second regression, the studentized residual with the largest magnitude was -2.1, providing no substantial evidence of additional outliers. All subsequent regressions discussed in this report omitted the August concentration considered to be an outlier.

Multiple linear regression equations were considered as an alternative to the simple linear regression. In separate regression analyses, parameters were estimated for flow velocity and sample depth with backscatter retained as a covariate. Results indicate that neither estimated parameter

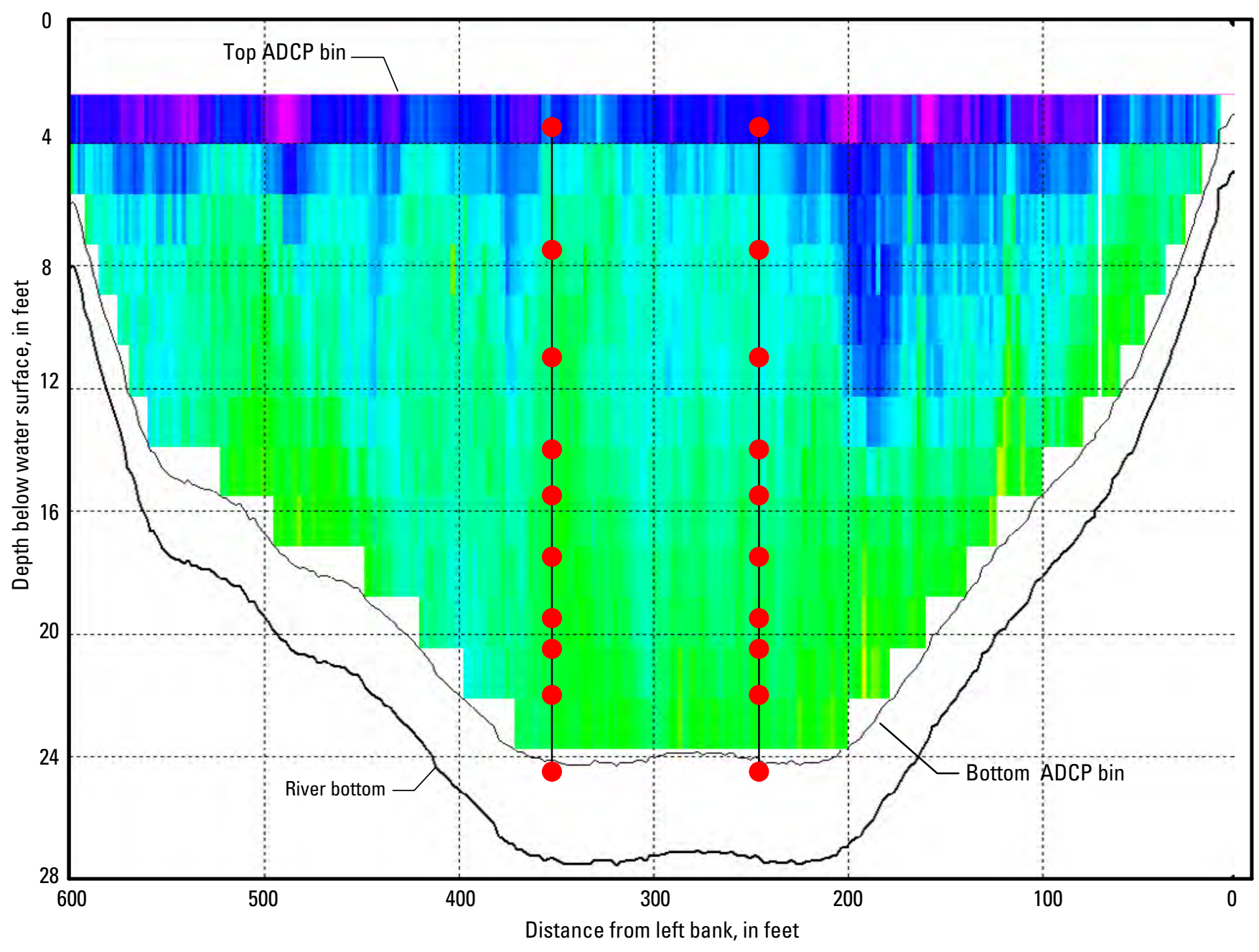

EXPLANATION

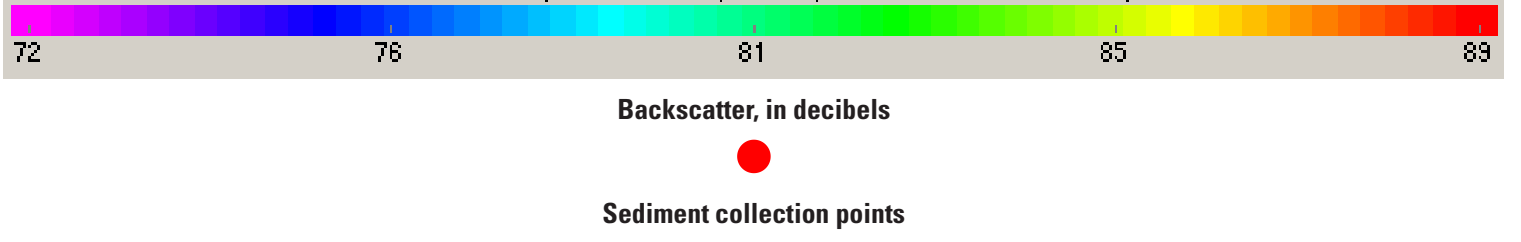

Figure 8. Locations of suspended-sediment concentration measurements along two vertical profiles sampled on August 12, 2009 from 11:03 to 11:07 a.m. at station 04157061, Saginaw River at Bay City, Michigan. (ADCP, acoustic Doppler current profiler) 


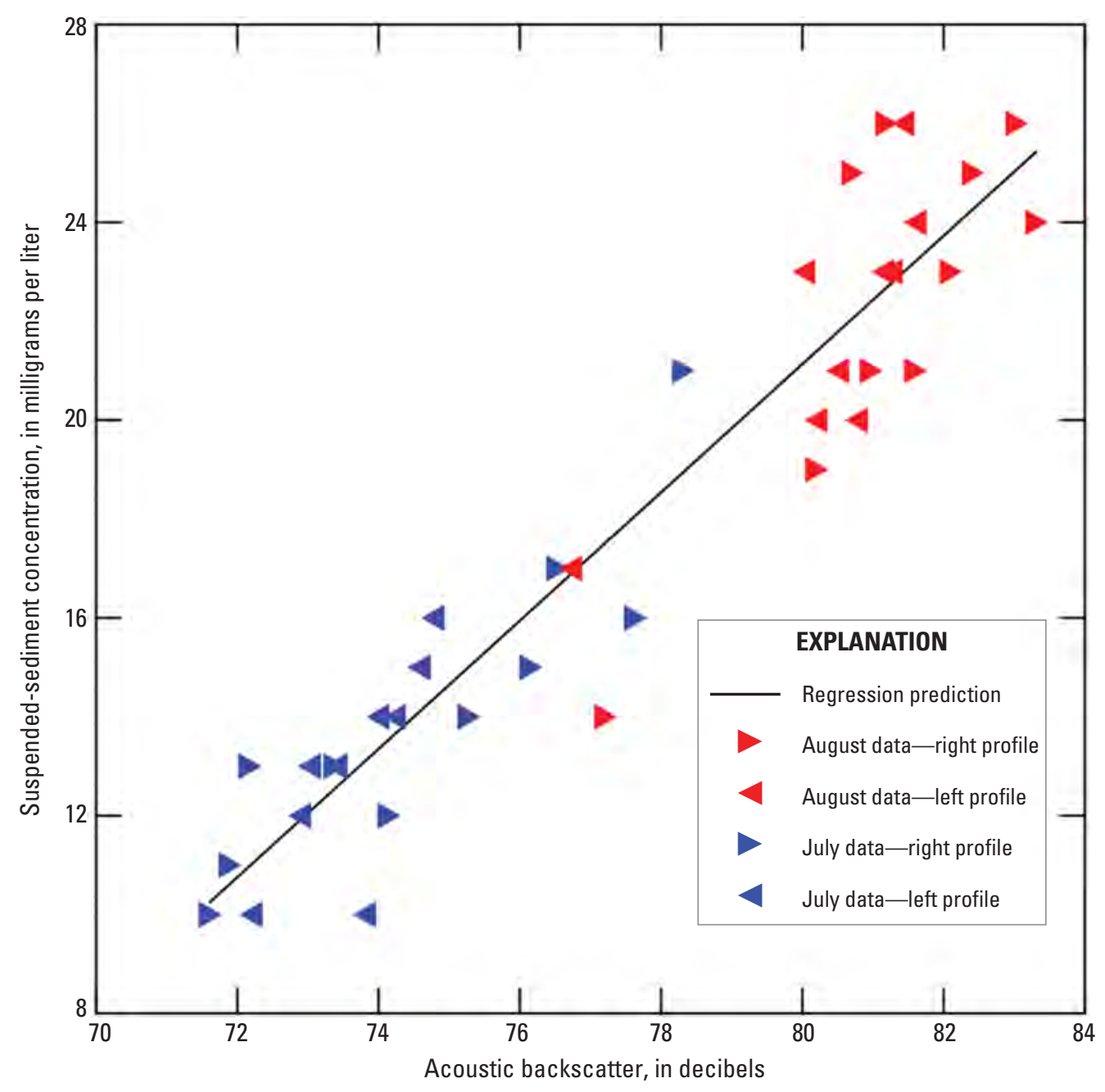

Figure 9 Relation between acoustic backscatter and suspended-sediment concentrations from samples along two vertical profiles in July and August 2009 at station 04157061, Saginaw River at Bay City, Michigan. was significantly different than zero given that backscatter data was included, with p-values of 0.2975 and 0.0804 , respectively.

A one-way analysis of covariance was used to investigate the relation between suspended-sediment concentration and depth by a group of variables formed from the four possible profile and sample month combinations. Results indicate that a parallel-lines model is appropriate, with each group member having a unique intercept but common relation to depth (slope term) (table 8 ). A simultaneous multiple comparison test by Scheffe (Stapleton, 1995), was used to determine which of the six possible pairwise comparisons of intercept terms were statistically different at the 5-percent level of significance. The six possible comparisons are: [JR-JL, JR-AR*, JR-AL*, JL-AR*, JL-AL*, AR-AL], where J indicates July, A indicates August, $\mathrm{R}$ indicates the right profile, and $\mathrm{L}$ indicates the left profile. Thus, JR-JL compares the intercept term between the right and left profiles in July. Pairs of intercept terms followed by an asterisk in the bracketed term above are significantly different. Essentially, no significant differences were detected between intercept terms for profiles within the same sample months at the 5 percent level of significance.

A one-way analysis of covariance also was conducted to assess whether the relation between backscatter and suspended-sediment concentration was effected by the month of the sampling events. Results indicate that neither the mean response (intercept term) nor the relation of backscatter to sediment concentration (slope term) differs significantly between July and August (table 9). Thus, the simple linear regression equation described in table 7 is considered adequate to model the available data. Given the limited data available to develop this equation, however, the utility of the corresponding relation also is limited. 
Table 7. Analysis of variance and parameter estimates for simple linear regression relating suspended-sediment concentrations with acoustic backscatter for two profiles sampled in July and August 2009 at station 04157061, Saginaw River at Bay City, Michigan.

$[<$, less than; - , no data $]$

\begin{tabular}{lccccc}
\hline \multicolumn{1}{c}{ Source } & Degrees of freedom & Sum of squares & Mean square & F Value & Probability of great F statistic \\
\hline Model & 1 & 909.6 & 909.6 & 319.2 & $<0.0001$ \\
Error & 37 & 105.4 & 2.850 & - & - \\
\hline \multicolumn{1}{c}{ Variable } & Degrees of freedom & Parameter estimate & Standard error & t Value & Probability of a greater Itl statistic \\
\hline Intercept & 1 & -82.625 & 5.6299 & -14.68 & $<0.0001$ \\
Backscatter & 1 & 1.297 & .07259 & 17.87 & $<.0001$ \\
\hline
\end{tabular}

Table 8. One-way analysis of covariance and parameter estimates relating suspended-sediment concentrations with depth by profile and sample month at station 04157061, Saginaw River at Bay City, Michigan.

$[<$, less than ;--, no data $]$

\begin{tabular}{lccccc}
\hline \multicolumn{1}{c}{ Source } & Degrees of freedom & Sum of squares & Mean square & F Value & Probability of great F statistic \\
\hline Month-profile & 3 & 721.19 & 240.397 & 74.78 & $<0.0001$ \\
Depth & 1 & 211.687 & 211.687 & 65.85 & $<.0001$ \\
Error & 34 & 109.302 & 3.215 & - & - \\
\hline \multirow{2}{*}{ Variable } & \multicolumn{1}{c}{$\begin{array}{c}\text { Month-profile } \\
\text { combination }\end{array}$} & Parameter estimate & Standard error & t Value & Probability of a greater Itl statistic \\
\hline Intercept & Average & 12.2103 & 0.76317 & 16.00 & $<0.0001$ \\
& July—right & -4.7404 & .49343 & -9.61 & $<.0001$ \\
& July—left & -3.8404 & .49343 & -7.78 & $<.0001$ \\
& August-right & 4.2213 & .51224 & 8.24 & $<.0001$ \\
& August-left & 4.3596 & .49343 & 8.84 & $<.0001$ \\
Depth & All & .3749 & .04620 & 8.11 & $<.0001$ \\
\hline
\end{tabular}


Table 9. Analysis of covariance and parameter estimates for linear regression relating suspended-sediment concentrations with acoustic backscatter for two profiles sampled in July and August 2009 at station 04157061, Saginaw River at Bay City, Michigan.

$[<$, less than; --, no data]

\begin{tabular}{|c|c|c|c|c|c|}
\hline Source & Degrees of freedom & Sum of squares & Mean square & F Value & Probability of great $F$ statistic \\
\hline Month & 1 & 1.524 & 1.524 & 0.53 & 0.4727 \\
\hline Backscatter & 1 & 222.36 & 222.36 & 76.9 & $<.0001$ \\
\hline $\begin{array}{l}\text { Backscatter X } \\
\text { month }\end{array}$ & 1 & 2.707 & 2.707 & .94 & .3399 \\
\hline Error & 35 & 101.20 & 2.892 & - & - \\
\hline Variable & Month & Parameter estimate & Standard error & t Value & Probability of a greater Itl statistic \\
\hline \multirow[t]{3}{*}{ Intercept } & Average & -92.843 & 12.596 & -7.37 & $<0.0001$ \\
\hline & July & 12.606 & 12.595 & 1.00 & .3238 \\
\hline & August & -12.606 & 12.596 & -1.00 & .3238 \\
\hline \multirow{3}{*}{ Backscatter } & Average & 1.422 & .1613 & 8.82 & $<.0001$ \\
\hline & July & -.156 & .1613 & -.97 & .3399 \\
\hline & August & .156 & .1613 & .97 & .3399 \\
\hline
\end{tabular}

\section{Detecting Temporal Variations in Composite Suspended Sediment Concentrations with Side-Looking Acoustic Backscatter Data}

A SonTek Argonaut-SL 500 (side-looking, $500 \mathrm{kHz}$ ) two-beam horizontal ADCP (HADCP) was mounted near the water-level gaging station at the Saginaw River at Bay City (fig. 3). The HADCP was located at approximately $43^{\circ} 36^{\prime} 35.3^{\prime \prime}$ north latitude and $83^{\circ} 53^{\prime} 11.2^{\prime \prime}$ west longitude. It was operated from April 21, 2009, until it was removed on Sept. 8, 2009. A third vertical beam on the ADCP measured the heights of water above the instrument (depths) during this period, which varied from 8.5 to $11.5 \mathrm{ft}$ with an average of about $10.5 \mathrm{ft}$.

The centerline of the 25-degree separation angle between the two slanted horizontal beams was directed approximately normal to the channel at an azimuth of about 135 degrees clockwise from true north. Along this azimuth, the acoustic signal was subdivided into 10 bins, each having a width of
$26 \mathrm{ft}$ and starting $33 \mathrm{ft}$ from the ADCP. No valid data could be obtained in the $33 \mathrm{ft}$ closest to the instrument, referred to as the blanking distance, because this distance (time) is required for the transducers to receive a signal following a transmission. Velocity, signal amplitude of backscatter, and noise characteristics are measured for each bin. In addition, an integrated velocity cell, beginning $33 \mathrm{ft}$ and ending $295 \mathrm{ft}$ from the instrument, provided average characteristics.

This HADCP monitored flow velocities ( $\mathrm{ft} / \mathrm{s}$ ), raw signal strengths as signal amplitudes (in counts), and instrument noise levels (in counts) at generally 15-minute intervals, with measurements averaged over 1-minute intervals. Flow direction is reported with respect to the beam azimuth, with downstream flow in the range of 0 to 180 degrees and upstream flow in the range of 180 to 360 degrees. During the monitoring period, reversals in flow direction were common, particularly in the summer months (fig. 10), although upstream (negative) flow velocities at Saginaw River at Bay City, Mich. (fig. 11) greater than $1 \mathrm{ft} / \mathrm{s}$ were uncommon. 
Figure 10. Frequency of flow reversals in the Saginaw River at Bay City, Michigan in May and August 2009.

Figure 11. Cumulative frequency distribution of integrated flow velocities in the Saginaw River at Bay City, Michigan from April to September 2009.
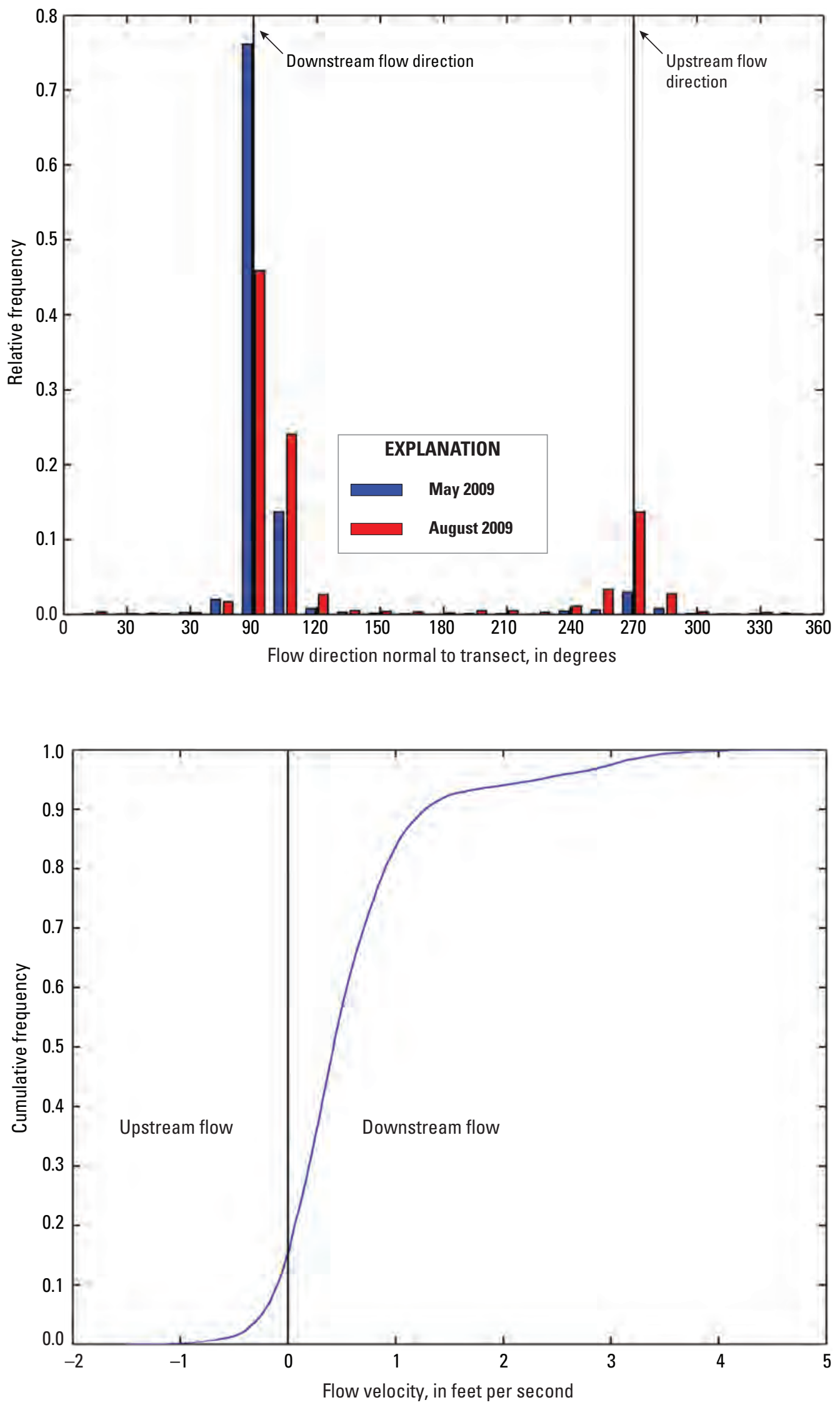
The acoustic backscatter described by the returning signal amplitude is affected by transmission losses that occur as the signal traverses the river. Thus for Saginaw River, the returned signal amplitude generally decreased with transmission distance across the river (fig. 12). Transmission losses that account for beam spreading and absorption by water are the primary components of these losses (Gartner, 2004), which vary strictly with distance to the bin centers. Distances to the bin centers, however, did not vary during the monitoring period. Thus, adjusting the returned signal amplitudes for these transmission losses would vary only the mean returning signal amplitude by a constant. Adding a constant to the mean signal amplitudes would not affect their statistical relation with mean suspended-sediment concentration in the cross section. Therefore, the mean returning signal amplitudes were left unadjusted in this comparison with suspended-sediment concentrations.

Noise is an unwanted acoustic signal that obscures the measurement of water velocities and backscatterers. The noise level for the Argonaut SL 500 is typically 30-35 counts (SonTek YSI Incorporated, 2009). This noise level also can be affected by the presence of electric motors or other electronic devices. During the monitoring interval, the median measured signal noise was 30.5 counts and ranged from 28 to 36 counts.

Signal amplitudes and noise levels were used to compute the signal-to-noise ratio (SNR) as:

$$
\text { SNR }=\frac{0.43 \cdot \text { decibels }}{\text { counts }}(\text { Signal Amplitude }- \text { Signal Noise }) \cdot \text { counts }
$$

where:

SNR

$$
\text { signal-to-noise ratio in decibels, }
$$

Signal Amplitude magnitude of the reflected acoustic signal, which varies with the amount and type of suspended material, and the distance from the transducer. The signal amplitude is attenuated with distance as a result of beam spreading and sound absorption. Signal amplitude is reported in logarithmic units of counts, and
Signal Noise

$$
\begin{aligned}
& \text { measured acoustic return when no } \\
& \text { acoustic pulse has been transmitted, and } \\
& \text { represents the ambient electronic noise. } \\
& \text { Signal noise is reported in logarithmic } \\
& \text { units of counts. }
\end{aligned}
$$

An SNR of 3 decibels is the minimum in which it is possible to interpret velocity and backscatter characteristics, and an SNR of 10 decibels is considered reasonably high. By this convention, velocity data in all bins across the river may be interpretable (fig. 12).

In 2009, eight DIMV suspended-sediment samples were obtained along a transect at the Saginaw River at Bay City. The suspended-sediment concentrations in the DIMV samples ranged from 14.0 to $29.0 \mathrm{mg} / \mathrm{L}$ with an average concentration of $19.5 \mathrm{mg} / \mathrm{L}$. No relation between these measured concentrations and signal amplitudes or signal-to-noise ratios (fig. 13) could readily be discerned from this limited dataset. Given the limited range of suspended-sediment concentration measurements and the difficulty of representing average transect concentrations from non-isokinetically collected sediment samples, the available data is considered inadequate to support an evaluation of the utility of the SonTek SL-500 for continuous monitoring of suspended-sediment concentrations. 
Figure 12. Relation between signal amplitude and signal-to-noise ratio from Argonaut 500 SL with distance to width bin at the Saginaw River at Bay City, Michigan, from April to September 2009. (ADCP, acoustic Doppler current profiler)

Figure 13. Composite suspended-sediment concentration measurements and contemporaneous measurements of acoustic amplitude and signal-to-noise ratios from a side-looking acoustic Doppler current profiler in the Saginaw River at Bay City, Michigan in 2009.
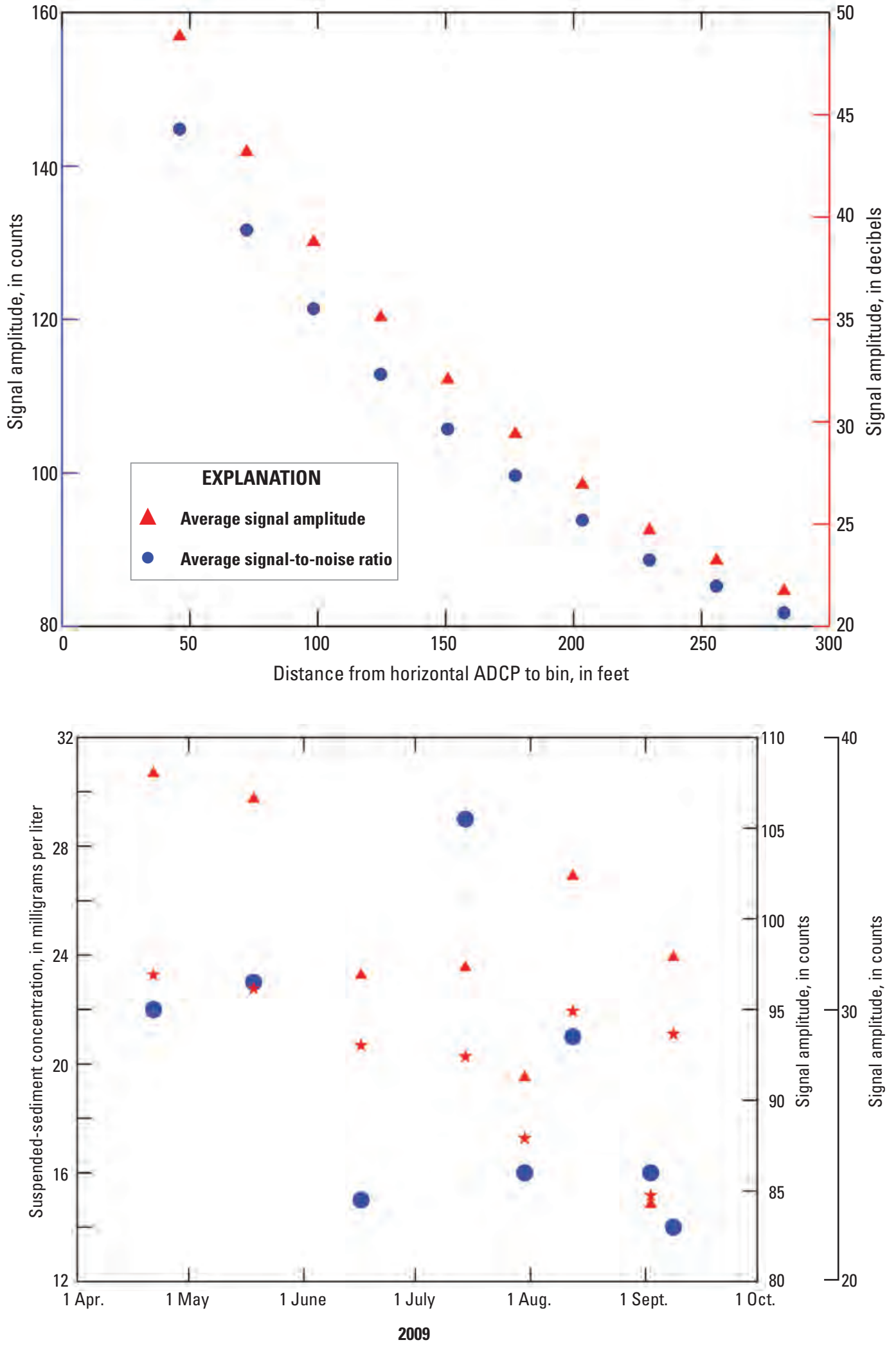

EXPLANATION

- Sediment concentration

- Signal amplitude

$\star \quad$ Signal-to-noise ratio 


\section{Summary}

The Michigan Department of Environmental Quality and the U.S. Geological Survey (USGS) developed a plan in 2009 to compare the effect of various streamflow and water-quality measurement techniques on streamflow and water-quality data for the Saginaw River, Michigan. The Saginaw River was selected for this research because it is the primary contributor of surface runoff to Saginaw Bay, Lake Huron, draining approximately 70 percent of the Saginaw Bay watershed. The Environmental Protection Agency lists the Saginaw River and Saginaw Bay system as an "Area of Concern" based, in part, on excessive sediment and nutrient loading to the system. Efforts to determine the load of sediment and nutrients to Saginaw Bay rely on streamflow and nutrient constituent concentrations collected in the Saginaw River. Current estimates of sediment and nutrient loads to this system use water-quality samples collected using grab techniques and flow data that are uncertain during some specific conditions. Results of these flow and water-quality sampling techniques were compared to results from alternative techniques between April and September 2009 at two locations in the Saginaw River.

Streamflow measurements were collected at Saginaw (04157000) and Bay City (04157061). Streamflow gaging using acoustic Doppler current profiling technology at Bay City was compared to traditional stage-discharge gaging techniques at Saginaw. In general, flow at station 04157061 was less than at the upstream station at Saginaw (04157000). Conditions resulting from the influence of Saginaw Bay on the Saginaw River made streamflow gaging problematic at the upstream location using traditional slope/stage techniques, as indicated by the large number of daily mean flow values listed as estimated. The acoustic gage technology used at Bay City was able to capture the velocity variability that resulted from the interactions of the Saginaw River and Saginaw Bay.

Water-quality samples were collected at two locations, on eight different dates, by the use of both surface-grab and DIMV sampling techniques. Sixteen paired samples were collected and analyzed for suspended sediment, turbidity, total phosphorus, total nitrogen, orthophosphate, nitrite, nitrate, and ammonia. Results indicate that concentrations of constituents associated with particulate material such as suspended sediment, turbidity, and total phosphorus collected through a DIMV sampling technique are statistically different than those collected through a surface-grab technique. In addition, the dissolved concentration of nitrite plus nitrate, was shown to be statistically different on the basis of sampling technique at the Saginaw water-quality station (04156999). Variability in constituent concentration attributed to sampling technique was greatest for suspended sediment followed by turbidity and total phosphorus, with median relative percent differences of 37,26 and 9.7 percent respectively.

Statistical methods were used to assess the feasibility of acoustic-backscatter information collected during flow measurements for estimating the suspended-sediment concentration of the river water. Discrete water samples were collected using a Van Dorn sampler at 10 depths $(3.5,7.5,11,14,15.5$, $17.5,19.5,20.5,22$, and $24.5 \mathrm{ft}$ below the water surface) along two vertical profiles near the center of the Saginaw River near Bay City. Samples were analyzed for suspended-sediment concentrations, and the data were then related through linear regression to acoustic-backscatter data that was collected simultaneously. Acoustic backscatter was strongly correlated to suspended-sediment concentrations, describing 89 percent of the variability through use of a linear regression. This correlation indicates potential for using acoustic-backscatter data to estimate suspended-sediment concentrations in the Saginaw River. Attempts to correlate DIMV suspended-sediment samples collected at eight separate times, to signal-to-noise ratio estimates recorded at the fixed acoustic gage deployed near Bay City resulted in poor correlation.

Results of the method comparison for two streamflowgaging and water-quality data-collection techniques indicate that uncertainty in constituent concentration and streamflow magnitude likely lead to uncertainty in nutrient- and sedimentload estimates for Saginaw Bay. Efforts to quantify phosphorus cycling in the Saginaw River and Saginaw Bay system may benefit from employing channel-integrating sampling strategies, like DIMV or EWI, to better characterize phosphorus inputs into Saginaw Bay. Grab sampling may be underpredicting phosphorus concentrations between 7.4 and 12 percent. In general, dissolved species concentrations, such as most nitrogen species, were not statistically different between DIMV and grab-sampling techniques. Therefore concentrations of nitrogen species are likely not biased low as a result of surface-grab techniques used. Additionally, streamflow gaging using acoustic gage technology would reduce uncertainty in flow estimates that arise from interactions between the Saginaw River and Saginaw Bay. Improved flow estimates would likely lead to improved constituent-load estimates for Saginaw Bay. 


\section{References Cited}

Conover, W. J., 1980, Practical nonparametric statistics: New York, t, 493 p.

Davis, B.E., 2005, A guide to the proper selection and use of Federally approved sediment and water-quality samplers: U.S. Geological Survey Open-File Report 2005-1087, 20 p.

Deines, K.L., 1999, Backscatter estimation using broadband acoustic Doppler current profilers, in Current measurement, 1999, Proceedings of the IEEE Sixth Working Conference on Current Measurement: San Diego, Calif., IEEE, p. 249-253.

Fishman, M.J., ed., 1993, Methods of analysis by the U.S. Geological Survey National Water Quality Laboratory-Methods for the determination of inorganic and organic constituents in water and fluvial sediments: U.S. Geological Survey Open-File Report 93-125, 217 p.

Gartner, J.W., 2004, Estimating suspended solids concentrations from backscatter intensity measured by acoustic Doppler current profiler in San Francisco Bay, California: Marine Geology, v. 211, p. 169-187.

Gibs, Jacob, Wilde, F.D., and Heckathorn, H.A., 2007, Use of multiparameter instruments for routine field measurements (ver. 1.1): U.S. Geological Survey Techniques of Water-Resources Investigations, book 9, chap. A6, section 6.8, accessed May 18, 2010, at http://pubs.water.usgs.gov/ twri9A/.

Guy, H.P., 1969, Laboratory theory and methods for sediment analysis: U.S. Geological Survey Techniques of WaterResources Investigations, book 5, chap. C1, 58 p.

Harmel, R.D., Slade, R.M., Jr., and Haney, R.L., 2010, Impact of sampling techniques on measured stormwater quality data for small streams: Journal of Environmental Quality, v. 39, p. 1734-1742.

Helsel, D.R., and Hirsch, R.M., 2002, Statistical methods in water resources: U.S. Geological Survey Techniques of Water-Resources Investigations, book 4, chap. A3, 524 p.

Horowitz, A.J., Rinella, F.A., Lamothe, Paul, Miller, T.L., Edwards, T.K., Roche, R.L., and Rickert, D.A., 1990, Variations in suspended sediment and associated trace element concentrations in selected riverine cross sections: Environmental Science and Technology, v. 24, no. 9, p.1313-1320.

Martin, G.R., Smoot, J.L., and White, K.D., 1992, A comparison of surface-grab and cross sectionally integrated stream-water-quality sampling methods: Water Environment Research, v. 64, no. 7, p. 866-876.
Michigan Department of Environmental Quality, 2006, Lake Huron Binational Partnership: Phosphorus in Saginaw Bay, have we met the target?: accessed March 2009 at http:// www.michigan.gov/documents/deq/deq-ogl-sbci-SagBayPhosphorus-Fact-Sheet-02-06_228177_7.pdf.

Morlock, S.E., Nguyen, H.T., and Ross, J.H., 2001, Feasibility of acoustic Doppler velocity meters for the production of discharge records from U.S. Geological Survey streamflowgaging stations: U.S. Geological Survey Water-Resources Investigations Report 01-4157, $56 \mathrm{p}$.

Multi-Resolution Land Characteristics Consortium, 2010, National Land Cover Database 2006: accessed April 5, 2010, at http://www.mrlc.gov/nlcd06_data.php.

National Oceanic and Atmospheric Administration, 2010, National Climatic Data Center climate database: accessed October 18, 2010, at $h t t p: / / w w w 7 . n c d c . n o a a . g o v / C D O / c d o$.

PRISM Climate Group, Oregon State University, 2008, Climate database: accessed June 2, 2010, at http://www.prism. oregonstate.edu.

Teledyne RD Instruments, 2011, WinRiver II Users Guide: San Diego, Calif., RD Instruments, 168 p., last accessed June 27, 2012, at http://www.rdinstruments.com/support/ SoftwareFirmware/x/cs/files/Manuals/WINRIV2UG_Dec11. PDF.

Simpson, M.R., 2001, Discharge measurement using a broadband acoustic Doppler current profiler: U.S. Geological Survey Open-File Report 2001-1, 123 p., accessed April 12, 2010, at http://pubs.usgs.gov/of/2001/ofr0101/text.pdf.

SonTek YSI Incorporated, 2009, Argonaut-SL System Manual, Firmware Version 12.0: San Diego, Calif., SonTek YSI Incorporated, 316 p., available upon request from support@ sontek.com.

Stapleton, J.H., 1995, Linear statistical models: Wiley Series in Probability and Statistics, 449 p.

Thorne, P.D., Vincent, C.E., Harcastle, P.J., Rehman, S., and Pearson, N. 1991, Measuring suspended sediment concentrations using acoustic backscatter devices: Marine Geology, v. 98 , p. $7-16$.

U.S. Environmental Protection Agency, 2009, Great Lakes Area of Concerns (AOCs): Saginaw River and Bay: U.S. Environmental Protection Agency Web page accessed March 2009 at http://www.epa.gov/glnpo/aoc/sagrivr.html.

U.S. Geological Survey, 2010, Water Resources data for the United States water year 2009: available online at http://wdr.water.usgs.gov/wy2009/search.jsp. 
Wilde, F.D., ed, 2006, Collection of water samples (ver. 2.0): U.S. Geological Survey Techniques of Water-Resources Investigations, book 9, chap. A4, accessed May 17, 2010, at http://water.usgs.gov/owq/FieldManual/chapter4/html/ Ch4_contents.html.
Wilde, F.D., Radtke, D.B., Gibs, Jacob, and Iwatsubo, R.T., eds., 2004 with updates through 2009, Processing of water samples (version 2.2): U.S. Geological Survey Techniques of Water-Resources Investigations, book 9, chap. A5, accessed May 18, 2010, at http://pubs.water.usgs.gov/ twri9A5\%. 



\section{ysts}
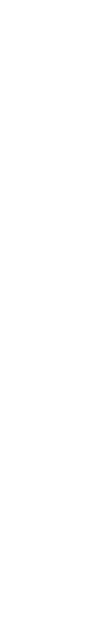